This is the peer reviewed version of the following article: Sigdel, S.R. et al. Moisture-mediated responsiveness of treeline shifts to global warming in the Himalayas in Global change biology (Ed. Wiley), vol. 24, issue 11 (Nov. 2018), p. 5549-5559.

Which has been published in final form at DOI 10.1111/gcb.14428

This article may be used for non-commercial purposes in accordance with Wiley Terms and Conditions for Use of Self-Archived Versions. This version is published under a "All rights reserved" license. 
Article type: Primary Research Article

\section{Moisture-mediated responsiveness of treeline shifts to global warming in the}

\section{Himalayas}

Running head: Moisture-mediated treeline shifts

Shalik Ram Sigdel ${ }^{1,2,3}$, Yafeng Wang ${ }^{1,4}$, J. Julio Camarero ${ }^{5}$, Haifeng Zhu ${ }^{1,2,6}$, Eryuan Liang ${ }^{1,2,6, *}$, Josep Peñuelas ${ }^{7,8}$

${ }^{1}$ Key laboratory of Alpine Ecology and Biodiversity, Institute of Tibetan Plateau Research, Chinese Academy of Sciences, Beijing, China

${ }^{2}$ Key Laboratory of Tibetan Environment Changes and Land Surface Processes, Institute of Tibetan Plateau Research, Chinese Academy of Sciences, Beijing, China

${ }^{3}$ University of Chinese Academy of Sciences, Beijing, China

${ }^{4}$ Colleges of Biology and the Environment, Nanjing Forestry University, Nanjing, China

${ }^{5}$ Instituto Pirenaico de Ecología, Consejo Superior de Investigaciones Científicas (IPE-CSIC), Zaragoza, Spain

${ }^{6} \mathrm{CAS}$ center for Excellence in Tibetan Plateau Earth Sciences, Beijing, China

${ }^{7}$ Global Ecology Unit CREAF-CSIC-UAB, CSIC, Barcelona, Catalonia, Spain.

${ }^{8}$ CREAF, Barcelona, Catalonia, Spain.

* Correspondence: Eryuan Liang, Institute of Tibetan Plateau Research, Chinese Academy of Sciences, Beijing 100101, China. Email: liangey@itpcas.ac.cn

KEY WORDS: Alpine treeline, treeline shift, tree recruitment, climate change, central Himalayas. 


\begin{abstract}
Among forest ecosystems, the alpine treeline ecotone can be considered to be a simplified model to study global ecology and climate change. Alpine treelines are expected to shift upwards in response to global warming given that tree recruitment and growth are assumed to be mainly limited by low temperatures. However, little is known whether precipitation and temperature interact to drive long-term Himalayan treeline dynamics. Tree growth is affected by spring rainfall in the central Himalayan treelines, being good locations for testing if, in addition to temperature, precipitation mediates treeline dynamics. To test this hypothesis, we reconstructed spatiotemporal variations in treeline dynamics in 20 plots located at six alpine treeline sites, dominated by two tree species (birch, fir), and situated along an east-west precipitation gradient in the central Himalayas. Our reconstructions evidenced that treelines shifted upward in response to recent climate warming, but their shift rates were primarily mediated by spring precipitation. The rate of upward shift was higher in the wettest eastern Himalayas, suggesting that its ascent rate was facilitated by spring precipitation. The drying tendency in association with the recent warming trends observed in the central Himalayas, however, will likely hinder an upslope advancement of alpine treelines and promote downward treeline shifts if moisture availability crosses a critical minimum threshold. Our study highlights the complexity of plant responses to climate and the need to consider multiple climate factors when analyzing treeline dynamics.
\end{abstract}




\section{INTRODUCTION}

Climate fundamentally controls the ranges of species and the rates of ecological processes in natural ecosystems (IPCC, 2014). Multiple evidences indicate that recent climatic changes have large effects on the structure and dynamics of plant terrestrial ecosystems (Lenoir, Gégout, Marquet, De Ruffray, \& Brisse, 2008; Peñuelas et al., 2013, Piao et al., 2014). Alpine plant communities and subalpine forests are potentially among the most affected terrestrial ecosystems, so treeline ecotones, which separate them, are a potential monitor of the impacts of climatic warming (Beckage et al., 2008; Harsch, Hulme, Mcglone, \& Duncan, 2009).

The growth limitation hypothesis states that tree growth at timberlines is primarily controlled by temperature during the growing season (Holtmeier \& Broll, 2005; Körner, 2012), so climatic warming should enhance growth and favor an upslope shift of alpine treelines. Warmer conditions have been associated with increased tree regeneration and encroachment at treeline ecotones worldwide (Camarero \& Gutiérrez, 2004; Liang, Wang, Eckstein \& Luo, 2011; Liang et al., 2016), and also with upward treeline shifts in many sites (Beckage et al., 2008; Du et al., 2018; Harsch, Hulme, Mcglone, \& Duncan, 2009; Huang et al., 2017; Peñuelas, Ogaya, Boada, \& Jump, 2007). Changes in the patterns of distributional limits of tree species at treelines, however, are not homogenous and depend on many local-scale interactions (Camarero et al., 2017; Case \& Duncan, 2014; Elliott, 2011; Kharuk, Ranson, Im, \& Vdovin, 2010; Liu \& Yin, 2013; Loranger, Zotz, \& Bader, 2017; Wang, Camarero, Luo, \& Liang, 2012; Wang, Liang, Sigdel, Liu, \& Camarero, 2017; Zhu, Woodall, \& Clark, 2012). For example, a global meta-analysis found that only about half of 166 treeline sites had shifted upward (Harsch, Hulme, Mcglone, \& Duncan, 2009), suggesting that the responses of alpine treelines to climatic warming are mediated by other factors such as biotic interactions (Harsch et al., 2012; Liang et al., 2016; Lyu, Zhang, Deng, \& Mäkinen, 2016), 
geomorphic processes (Macias-Fauria \& Johnson, 2013; Resler, Butler, \& Malanson, 2005) or topography (Elliot \& Cowell, 2015; Holtmeier \& Broll, 2005; Li \& Yang, 2004). In addition, tree growth and recruitment at treeline often react differently to climatic variations (Daniels \& Veblen, 2004). Soil moisture is an important factor for tree growth and seedling establishment at treelines (Batllori \& Gutiérrez, 2008; Piper et al., 2016), indicating the importance of precipitation and soilmoisture availability for treeline dynamics. Altered precipitation regimes may promote treeline advances in exceptional cases by changing, for example, patterns of snow distribution (Hagedorn et al., 2014). Pollen-based models have indicated that treeline altitude in tropical Africa was strongly controlled by changes in precipitation during the last glacial maximum (Wu, Guiot, Brewer, Guo, \& Peng, 2007). Furthermore, several studies have shown that interactions between temperature and precipitation leading to dry conditions limit seedling establishment and tree species shifts in western North America (Elliott, 2012; Elliott \& Petruccelli, 2018; Kueppers et al., 2017; Lloyd \& Graumlich, 1997; Moyes, Germino, \& Kueppers, 2015). Whether temperature and precipitation interact to drive long-term treeline dynamics, however, remains unknown across the Himalayas and surrounding mountains.

The Himalayas and Tibetan Plateau hold the world's highest mountain systems, and the highest treelines in the northern Hemisphere (Miehe, Miehe, Vogel, Co, \& La, 2007), and have a broad gradient of bioclimatic zones along their altitudinal gradient. Himalayan birch (Betula utilis D. Don) and Himalayan fir (Abies spectabilis (D. Don) Spach) form the natural treelines near 4000 m a.s.l. in the central Himalayas. Himalayan alpine treelines thus constitute suitable locations for determining the impacts of climate change on forest ecosystems. A recent study reported that the growth of Himalayan birch at the treeline was primarily limited by pre-monsoon precipitation (Liang, Dawadi, Pederson, \& Eckstein, 2014) and its spatial distribution depends on soil moisture 
availability (Shrestha, Ghimire, Lekhak, \& Jha, 2007). Precipitation is expected to control the rates of shifts of such moisture-driven alpine treelines. Local-scale studies (Chhetri \& Cairns, 2018; Gaire, Koirala, Bhuju, \& Borgaonkar, 2014; Shrestha, Hofgaard, \& Vandvik, 2014; Tiwari, Fan, Jump, Li, \& Zhou, 2017) have shown treeline-shift rates differ among specific areas; however, these studies may not be able to disentangle the effects of precipitation on treeline dynamics from other local-scale interactions due to a lack of approaches considering a macroscale precipitation gradient, i.e. the longitudinal range $80-88 \mathrm{E}$ and approximately $800 \mathrm{~km}$ across the central Himalayas. Macroscale studies encompassing east-west precipitation gradients are therefore necessary to determine the responses of alpine treelines to temperature and precipitation changes across the central Himalayas.

The specific objectives of this study were to: (i) reconstruct the spatiotemporal patterns of treeline shifts during the last 150 years across the central Himalayas, and (ii) determine the role played by precipitation on the dynamics of Himalayan treelines. Based on the evidence that precipitation decreases westwards across the central Himalayas, we hypothesized that warminginduced treeline shifts would be mediated by regional precipitation gradients, and would be more substantial in the east. We also hypothesized that the components of these shifts (tree growth, tree recruitment, and treeline position) would be uncoupled and shaped by different climatic factors along this precipitation gradient.

\section{MATERIALS AND METHODS}

\section{Study area}

We established a network of 20 treeline plots at six sites located across an east-west gradient in Nepal to study the macroscale dynamics of treelines of two major treeline species, Himalayan 
birch (Betula utilis D. Don) and Himalayan fir (Abies spectabilis (D. Don) Spach), across the central Himalayas (Figure 1). The climate of this region is influenced by two weather systems. The eastern region is highly influenced by the southern Indian monsoon during summer, and the western region is influenced by westerly winds during winter (Yao et al., 2012). The total annual rainfall ranges from about $3500 \mathrm{~mm}$ in the east to $800 \mathrm{~mm}$ in the west. About $80 \%$ of the precipitation falls during the monsoon season. The mean annual temperatures along the treeline ecotone range from $3.7^{\circ}$ to $4.9^{\circ} \mathrm{C}$, and the mean soil temperature at the treeline during the growing season is about $7.5 \pm 0.6{ }^{\circ} \mathrm{C}$ (Müller et al., 2016), slightly higher than that recorded on the southeastern Tibetan plateau $\left(6.0 \pm 0.3{ }^{\circ} \mathrm{C}\right)$ (Liang et al., 2016) and the global average $(6.7 \pm 0.8$ $\left.{ }^{\circ} \mathrm{C}\right)$ (Körner \& Paulsen, 2004).

\section{Research plots and sampling design}

The position of the upper treeline was defined by the presence of upright trees with a minimum height of $2 \mathrm{~m}$ at the maximum altitude and a continuous distribution above the timberline (forest coverage $>30 \%$ ) in the plots (Camarero \& Gutiérrez, 2004; Liang, Wang, Eckstein, \& Luo, 2011, Liang et al., 2016). Treeline altitude varies from 3800 to $4250 \mathrm{~m}$ a.s.l. All plots included the upper limits of the tree species in closed forests following previous field protocols (Camarero \& Gutiérrez, 2004; Liang, Wang, Eckstein, \& Luo, 2011; Liang et al., 2016). Fieldwork was

conducted in April-June 2014, September-November 2014 and April-June 2015. Permanent rectangular plots were established (all were of size $30 \mathrm{~m} \times 150 \mathrm{~m}$ except in site MN3 where it was $30 \mathrm{~m} \times 100 \mathrm{~m}$ ) on gentle slopes and distant from previously disturbed areas affected by landslides or avalanches. The treeline network included fourteen birch plots and six fir plots. The plots had their longer sides (y-axis) parallel to the altitudinal gradient (Camarero \& Gutiérrez, 2004). The 
$x, y$ origin $(0,0)$ for all plots was in the lower left corner facing upslope. The geographic information of all four corners was noted using GPS. The location of each tree of the target species was noted relative to the origin $(x, y=0,0)$. The diameter at breast height $(\mathrm{DBH})$ of each tree in the plot was measured at $1.3 \mathrm{~m}$ using diameter tapes. Tree height was measured using clinometers for trees with height $>2 \mathrm{~m}$ and a measuring stick for trees with height $\leq 2 \mathrm{~m}$ (Wang, Zhu, Liang, \& Camarero, 2016). The average height and coverage of shrubs and grasses were measured along altitudinal transects from the current treeline to $10 \mathrm{~m}$ above the treeline and the vegetation thickness index (TI) was calculated as average plant height $\times$ coverage (Liang et al., 2016).

A core was collected using an increment borer as close as possible to the ground from the main stem of each living tree with a $\mathrm{DBH}>5 \mathrm{~cm}$ for estimating the germination dates of the trees (in total, $\mathrm{n}=1594$ birches and $\mathrm{n}=414$ firs were sampled). A core was similarly collected at a height of $2 \mathrm{~m}$ for each site and species ( $\mathrm{n}=110$ birches and $\mathrm{n}=37$ firs) for calculating the age at $2 \mathrm{~m}$ (Table $\mathrm{S} 1$ ), which was then used to identify the treeline position (altitude of trees $2 \mathrm{~m}$ tall). The ages of seedlings and saplings (individuals with DBHs $<5 \mathrm{~cm}$ ) were estimated by counting terminal branch whorls and scars along the main stem (Camarero \& Gutiérrez, 2004; Liang, Wang, Eckstein, \& Luo, 2011). Then, wood sections were collected from the root collar ( $\mathrm{n}=105$ trees) to validate the estimates. The estimated ages of the firs were very similar ( $\pm 1.5 \mathrm{yrs}$.$) to the estimated germination$ dates, but the estimated ages of birches were four years older than the germination dates. AgeDBH relationships were then determined for each site and species using linear regression models (Figure S1). Age and DBH were highly correlated $(P<0.001)$ for all treeline sites and species. These relationships were used to estimate the age of trees with a rotten center or missing pith.

\section{Data analyses}


The dynamics of recruitment on a decadal scale were reconstructed from the tree ages for each site and compared with past climatic records. An integrated ice-core $\delta^{18} \mathrm{O}$ series from the Tibetan Plateau was used as a proxy of annual and summer temperature (Thompson et al., 2006), and chronologies derived from the width of tree rings of the moisture-sensitive Himalayan birch from the central Himalayas (Liang, Dawadi, Pederson, \& Eckstein, 2014) were used as a proxy of pre-monsoon precipitation. Similarly, the spatiotemporal variability of tree density and treeline position were characterized for 50-year long intervals (Camarero \& Gutiérrez, 2004; Liang, Wang, Eckstein, \& Luo, 2011; Liang et al., 2016) (Figure S2).

We developed a comprehensive data set of several potential explanatory variables of treeline shifts: aspect, slope, altitude, tree species, shrub and herb coverage above the treeline, TI, distance between a treeline and a species line (TL-SL), mean/total annual, spring, summer and winter temperatures (AT, SPT, SUT and WT) and precipitation (AP, SPP, SUP and WP) and changes in annual, spring, summer and winter temperature (CAT, CSPT, CSUT and CWT) and precipitation (CAP, CSPP, CSUP and CWP). We also considered annual mean maximum (ATmax) and minimum temperatures (ATmin).

To obtain climate data, we used high-resolution interpolated monthly climatic data (temperature and precipitation) due to the paucity of instrumental climatic data for high Himalayan altitudes. Temperature data were retrieved from the Climate Research Unit (CRU) TS3.23 database, which has a spatial resolution of $0.5^{\circ}$ (Harris, Jones, Osborn, \& Lister, 2014). We obtained these data from the $0.5^{\circ}$ grids located nearest to each sampling site and applied a published standard rate of temperature lapse to calculate site-specific temperature after adjusting altitudinal effect (Kattel et al., 2013). Temperature data after 1970 were used for the analyses because the climatic data were most reliable for this period. In our early studies in the Langtang 
valley and Mt. Everest, we tested the representative of variations of CRU gridded temperature (Dawadi, Liang, Tian, Devkota, \& Yao, 2013; Liang, Dawadi, Pederson, \& Eckstein, 2014), and showed that the variations of the gridded monthly temperature appear to represent well those thermal conditions in the treeline sampling areas.

High-resolution $\left(0.25^{\circ}\right.$ grid $)$ precipitation data were retrieved from the Tropical Rainfall Measuring Mission (TRMM) satellite, available online (http://giovanni.gsfc.nasa.gov/giovanni/) since 1998. These data were not corrected for the effects of altitude, because few local data were available for local precipitation. TRMM radar data have been widely used to show the relationship between precipitation and topography in the Himalayas (Bookhagen \& Burbank, 2006; Shrestha, Singh, \& Nakamura, 2012). For example, TRMM data capture a clear zonal distribution pattern of rainfall along the southern periphery of the central Himalayas (Liang, Dawadi, Pederson, \& Eckstein, 2014). We also retrieved evapotranspiration data (1980-2010, $0.25^{\circ}$ spatial resolution) from the Global Land Data Assimilation System (GLDAS) available online (http://giovanni.gsfc.nasa.gov/giovanni/).

A generalized linear model (GLM) was used to identify the variables responsible for the rates of treeline shift during the last 150 years using R (R Development Core Team, 2017) and we used the R "relaimpo" package to evaluate the relative importance of the variables in linear regression models based on the successive-sweep method (Grömping, 2006). Partial correlation analyses were also used to measure the linear relationship between two variables, such as treeline shift and summer monsoon precipitation, after having excluded the effect of a third variable, such as premonsoon precipitation.

\section{RESULTS}


All plots showed a common demographic structure, characterized by increasing tree recruitment in recent decades, particularly after the 1940s (Figure 2). The decadal rate of tree recruitment was significantly correlated $\left(P<0.05\right.$; Table S2) with several temperature proxies $\left(\delta^{18} \mathrm{O}\right.$ series from ice cores from the Tibetan Plateau). Tree recruitment was mainly linked to the rapid temperature increase during the second half of the $20^{\text {th }}$ century. Tree recruitment above the current treeline was higher for birch than fir.

We reconstructed the spatiotemporal variation in tree density and treeline position based on the age and height of individual trees for 20 treeline plots situated at six Himalayan sites (Figure $\mathrm{S} 2$ ). The average upward rates of treeline shift during the last 150 years ranged from 0 to $0.37 \mathrm{~m}$ $\mathrm{y}^{-1}$ with an average of $0.11 \pm 0.10 \mathrm{~m} \mathrm{y}^{-1}$, i.e. the ascent varied from 0 to $56 \mathrm{~m}$. Treeline positions in eight of the 20 plots have been static or have changed little during the last 150 years. No dead trees or stumps were found above the current treelines, indicating that the sampled trees were the first generation recruited above the treeline during at least the last two centuries and suggesting that the subalpine forest was established during the last 2-3 centuries (Figure S2). The rate of treeline advance in our study, however, was not high but it increased in eastern Nepal (0.20-0.37 $\mathrm{m} \mathrm{yr}^{-1}$; see Table 1).

The rates of treeline shifts varied significantly along the east-west precipitation gradient, suggesting that precipitation and temperature interacted to control the regional treeline dynamics. Generalized linear models indicated that spring precipitation and mean annual maximum temperature together explained $60.5 \%$ of the total variance in treeline shift (Table 2 and Figure 3 ). Nevertheless, spring precipitation contributed more than mean annual maximum temperature (53\% vs. $47 \%)$ to explain treeline-shift rates and it was the most significant driver $(\mathrm{P}<0.001)$, followed by mean annual maximum temperature $(\mathrm{P}<0.01)$. As showed by the partial correlation 
analysis, summer monsoon precipitation is not a critical factor in controlling treeline shifts (Table S3). Spring precipitation is significantly more important than summer precipitation in affecting treeline dynamics.

We assessed the role of biotic interactions by calculating a vegetation thickness index (TI) which is the product of cover and height of alpine plant vegetation (shrubs, grasses) situated just above the treeline (Liang et al., 2016). The TI did not have a significant effect on treeline-shift rates, which may be explained because dwarf shrubs were sparsely distributed above the current treelines across all sites, resulting in a low TI $(0.12-0.82$; see Table 1$)$.

\section{DISCUSSION}

Increasing tree recruitment at treeline ecotones in recent decades is likely linked to ongoing climatic warming. Warmer and stable spring and summer conditions can improve seed germination and increase the survival of seedlings at treelines, thus promoting tree recruitment (Camarero \& Gutiérrez, 2004; Körner, 2012). Higher recruitment of birch above current treeline may be due to the fact that light seeds can be easily dispersed by wind long distances beyond the current treeline (Nathan \& Muller-Landau, 2000). Himalayan fir, however, produces seeds within a cone that probably are not dispersed such long distances by wind (Coates, 2002; Greene \& Johnson, 1995).

Both species are less preferred to browse by wildlife and livestock. The warming-induced increase in recruitment therefore was likely affected by species-specific dispersal traits (e.g. seed mass and dispersal ability, masting frequency). Similar recruitment trends were also observed at other treelines on the Tibetan Plateau (Liang, Wang, Eckstein, \& Luo, 2011; Liang et al., 2016; Wang, Pederson et al., 2016), in the Green Mountains of Vermont in northeastern USA (Beckage et al., 2008), the Siberian mountains and the Urals in Russia (Hagedorn et al., 2014; Kharuk, Ranson, 
Im, \& Vdovin, 2010; Kirdyanov et al., 2012), and the Pyrenees in Spain (Batllori \& Gutiérrez, 2008; Camarero \& Gutiérrez, 2004).

The treeline positions and their shift rate in the central Himalayas were spatially heterogeneous. Indeed, such results essentially match those from the most recent meta-analysis (Harsch, Hulme, Mcglone, \& Duncan, 2009), with 52\% of sites showing treeline advance upslope worldwide. The average rate of treeline shift was lower than those observed on the Tibetan Plateau $\left(0.29 \pm 0.29 \mathrm{~m} \mathrm{yr}^{-1}\right)$ (Liang et al., 2016) and in the European Alps $\left(0.65 \mathrm{~m} \mathrm{yr}^{-1}\right)$ (Lenoir et al., 2008), southeastern Swiss Alps $\left(0.28 \pm 0.15 \mathrm{~m} \mathrm{yr}^{-1}\right)$ (Walther, Beißner, \& Burga, 2005), Vermont Mountains (2.62 m yr$\left.{ }^{-1}\right)$ (Beckage et al., 2008), Urals and Siberian mountains $\left(0.30 \mathrm{~m} \mathrm{yr}^{-1}\right)$ (Hagedorn et al., 2014; Kharuk, Ranson, Im, \& Vdovin, 2010), Swedish Scandes (1.04 m yr ${ }^{-1}$ ) (Kullman \& Öberg, 2009), and Spanish Pyrenees (0.61 m yr $\left.{ }^{-1}\right)$ (Camarero \& Gutiérrez, 2004). Few studies have been conducted in the central Himalayas on treeline dynamics, and the results have been inconsistent. Some studies have reported rapid upslope shifts of treelines $(0.52-2.61 \mathrm{~m}$ $\mathrm{yr}^{-1}$; cf. Gaire, Koirala, Bhuju, \& Borgaonkar, 2014; Tiwari, Fan, Jump, Li, \& Zhou, 2017), and others have reported static treelines (Shrestha, Hofgaard, \& Vandvik, 2014). Overall, the reconstructed and reported treeline-shift rates are low (on average less than $1 \mathrm{~m} \mathrm{yr}^{-1}$ ) which suggests that either the positive response of treeline to rising temperatures is low or there are other environmental factors mediating and reverting the expected upward trends.

Spring precipitation was the most crucial driver for determining changes in treeline position across the central Himalayas. The rates of treeline shifts were lower at the western Manang (MA), Jumla (J) and Humla (HM) sites than at the eastern study sites. Precipitation in the central Himalayas is regulated by two weather systems, a summer monsoon during June to September and westerly winds during November to May (Yao et al., 2012). Likewise, western Nepal is situated 
between the influences of a cyclonic cell to the west and an anti-cyclonic cell to the east, which causes substantial dry conditions and decreasing trends of precipitation westward (Wang, Yoon, Gillies, \& Cho, 2013). We observed a higher treeline-shift rate in the eastern study area which supports the idea that moisture drives treeline-shift rates across the studied E-W precipitation gradient. These results are supported by the facts that tree growth is also constrained by low spring precipitation (Liang, Dawadi, Pederson, \& Eckstein, 2014) and the distribution of birch trees is affected by the availability of soil moisture (Shrestha, Ghimire, Lekhak, \& Jha, 2007). The sparse occurrence of shrubs in the study treelines may facilitate seedling establishment and allowed upward treeline advancement (Chhetri \& Cairns, 2015; Liang et al., 2016). The TI was lower in the study Himalayan treelines (mean TI $=0.35)$ than in the Tibetan Plateau (mean TI $=1.55$ ) where dense shrub communities suppressed treeline advance when TI was above 0.8 (Liang et al., 2016).

Temperature may not drive treeline shift rates per se but through interactions with precipitation and water available to trees. Moisture stress can have significant and negative influences on seed production and viability of seeds across the circumarctic forest tundra ecotone, being a bottleneck to treeline advance (Brown et al., 2018). As shown in western North America, dry conditions can limit seedling establishment and hence tree species shifts (Elliott, 2012; Elliott \& Petruccelli, 2018; Kueppers et al., 2017; Lloyd \& Graumlich, 1997; Moyes, Germino, \& Kueppers, 2015). Warmer temperatures could lead to a deficit in soil moisture driven by increased evapotranspiration at alpine treeline ecotones (Trujillo, Molotch, Goulden, Kelly, \& Bales, 2012). Satellite-derived estimates suggest that the winter rate of evapotranspiration has increased significantly during the last three decades (Figure S3) at four of the six study regions, which might negatively affect moisture availability during spring. Our analysis of spring precipitation and temperature of nearby treeline sites found that precipitation has decreased significantly at some 
sites, whereas air temperature has increased at all sites (Figure S4), in agreement with observations of shrinking Himalayan glaciers linked to rising temperatures (Yao et al., 2012). Decreasing trends in the snow accumulation (Thompson et al., 2000) and increasing values of drought severity reflected by changes in the Palmer Drought Severity Index (Sano, Ramesh, Sheshshayee, \& Sukumar, 2011) during the last 150 years suggested weakening South Asian Monsoon (Figure S5). Furthermore, warming will enhance transpiration, and intensify photoinhibition and hydraulic failure in drought-prone sites (Allen, Breshears, \& Mcdowell, 2015; Choat et al., 2018). Hence, interactions between spring precipitation and the annual maximum temperature are likely driving treeline shifts across the dry Himalayas.

Tree recruitment, growth and treeline shifts were regulated by distinct climatic factors, supporting our second hypothesis. Tree growth at the upper timberline of Himalayan birch and Himalayan fir was mainly limited by low pre-monsoon precipitation in the central Himalayas (Liang, Dawadi, Pederson, \& Eckstein, 2014; Tiwari, Fan, Jump, Li, \& Zhou, 2017), being different with thermal treelines and cold biomes of the Northern Hemisphere (Li et al., 2017; Rossi et al., 2016). Drought stress delays the onset of cambial cell division and reduces the growth rate at drought-prone forest sites (Ren et al., 2018). A high percentage of locally missing rings coincided with dry and warm pre-monsoon seasons at the upper timberline of Himalayan birch in the central Himalayas, providing additional evidence that moisture controls its growth and survival (Liang, Dawadi, Pederson, \& Eckstein, 2014). In contrast, long-term tree recruitment was constrained by cold temperatures, so the treeline shifts were jointly controlled by both precipitation and temperature. These results differed from those observed at temperature-limited treelines, where tree growth, tree recruitment, and treeline position usually responded consistently to temperature (Harte \& Shaw, 1995), but were in agreement with observations on Nothofagus 
pumilio treelines from Patagonia, on Larix sibirica forest-steppe ecotone in northern Mongolia and several conifer species in western North America whose dynamics depend on precipitation and temperature (Daniels \& Veblen, 2004; Dulamsuren, Hauck, \& Leuschner, 2010; Elliott \& Cowell, 2015; Elliott \& Petruccelli, 2018; Fajardo \& McIntire, 2012; Kueppers et al., 2017; Morgan, Losey, \& Trout, 2014; Moyes, Germino, \& Kueppers, 2015).

To conclude, treeline shifts in the Himalayas are better explained by interactions between precipitation and temperature than to either alone, and their interaction may lead to changes in the availability of soil moisture to trees. The upslope treeline shift rates over the last 150 years were low and its pace was primarily controlled by spring precipitation in association with changes in mean annual maximum temperature. Warm and moist spring climatic conditions led to increased tree recruitment, thereby facilitating their ascent. The drying tendency in association with the recent warming trends in the central Himalayas, however, will likely hinder an upslope advancement of alpine treelines. Future studies should evaluate if drying and warming climate trends may even promote downward treeline shifts after moisture availability crosses a critical low threshold.

\section{ACKNOWLEDGEMENTS}

This work was supported by the National Natural Science Foundation of China (41661144040), the Strategic Priority Research Program of Chinese Academy of Sciences (XDA20050101), the National Science Fund for Distinguished Young Scholars (41525001), and the Youth Innovation Promotion Association, CAS. SRS was supported by the CAS-TWAS President's Fellowship Program for International Ph.D. students, and Chinese Academy of Sciences President's International Fellowship Initiative (2018PC0040). JP acknowledges the financial support from 
the European Research Council Synergy grant ERC-SyG-2013-610028 IMBALANCE-P. The Department of National Park and Wildlife Conservation, Government of Nepal, is especially acknowledged for granting research permission. We thank KCRE (Kathmandu Center for Research and Education, CAS-TU), Biraz Chaudhary, Samresh Rai, Anuj Thapa Magar and several local residents for their help during the fieldwork, and Aaron M. Ellison for helpful comments on an earlier version. 


\section{REFERENCES}

Allen, C. D., Breshears, D. D., \& Mcdowell, N. G. (2015). On underestimation of global vulnerability to tree mortality and forest die - off from hotter drought in the Anthropocene. Ecosphere, 6, 1-55. https://doi.org/10.1890/ES15-00203.1

Batllori, E., \& Gutiérrez, E. (2008). Regional tree line dynamics in response to global change in the Pyrenees. Journal of Ecology, 96, 1275-1288. https://doi.org/10.1111/j.13652745.2008.01429.x

Beckage, B., Osborne, B., Gavin, D. G., Pucko, C., Siccama, T., \& Perkins, T. (2008). A rapid upward shift of a forest ecotone during 40 years of warming in the Green Mountains of Vermont. Proceedings of the National Academy of Sciences, 105, 4197-4202. https://doi.org/10.1073/pnas.0708921105

Bookhagen, B., \& Burbank, D. W. (2006). Topography, relief, and TRMM-derived rainfall variations along the Himalaya. Geophysical Research Letters, 33, L08405. https://doi.org/ 10.1029/2006GL026037.

Brown, C. D., Dufour-Tremblay, G., Jameson, R. G., Mamet, S. D., Trant, A. J., Walker X. J., ....Johnstone, J. F. (2018). Reproduction as a bottleneck to treeline advance across the circumarctic forest tundra ecotone. Ecography, https://doi.org/10.1111/ecog.03733

Case, B. S., \& Duncan, R. P. (2014). A novel framework for disentangling the scale-dependent influences of abiotic factors on alpine treeline position. Ecography, 37, 838-851. https://doi.org/10.1111/ecog.00280

Camarero, J. J., \& Gutiérrez, E. (2004). Pace and pattern of recent treeline dynamics: response of ecotones to climatic variability in the Spanish Pyrenees. Climatic Change, 63, 181-200. https://doi.org/10.1023/B:CLIM.0000018507.71343.46 
Camarero, J. J., Linares, J. C., García-Cervigón, A. I., Batllori, E., Martínez, I., \& Gutiérrez, E. (2017). Back to the future: the responses of alpine treelines to climate warming are constrained by the current ecotone structure. Ecosystems, 20, 683-700. https://doi.org/10.1007/s10021016-0046-3

Chhetri, P. K., \& Cairns, D. M. (2015). Contemporary and historic population structure of Abies spectabilis at treeline in Barun valley, eastern Nepal Himalaya. Journal of Mountain Science, 12, 558-570. https://doi.org/10.1007/s11629-015-3454-5.

Chhetri, P. K., \& Cairns, D. M. (2018). Low recruitment above treeline indicates treeline stability under changing climate in Dhorpatan Hunting Reserve, Western Nepal. Physical Geography, 39, 329-342. https://doi.org/10.1080/02723646.2018.1428266

Choat, B., Brodribb, T. J., Brodersen, C. R., Duursma, R. A., López, R., \& Medlyn, B. E. (2018). Triggers of tree mortality under drought. Nature, 558, 531-539. https://doi.org/10.1038/s41586-018-0240-x

Coates, K. D. (2002). Tree recruitment in gaps of various size, clearcuts and undisturbed mixed forest of interior British Columbia, Canada. Forest Ecology and Management, 155, 387-398. https://doi.org/10.1016/S0378-1127(01)00574-6

Daniels, L. D., \& Veblen, T. T. (2004). Spatiotemporal influences of climate on altitudinal treeline in northern Patagonia. Ecology, 85, 1284-1296. https://doi.org/10.1890/03-0092

Dawadi, B., Liang, E., Tian, L., Devkota, L. P., \& Yao, T. (2013). Pre-monsoon precipitation signal in tree rings of timberline Betula utilis in the central Himalayas. Quaternary International, 283, 72-77. https://doi.org/10.1016/j.quaint.2012.05.039

Du, H., Liu, J., Li, M. H., Büntgen, U., Yang, Y., Wang, L., .. He, H. S. (2018). Warming-induced upward migration of the alpine treeline in the Changbai Mountains, northeast China. Global 
Change Biology, 24, 1256-1266. https://doi.org/10.1111/gcb.13963

Dulamsuren, C., Hauck, M., \& Leuschner, C. (2010). Recent drought stress leads to growth reductions in Larix sibirica in the western Khentey, Mongolia. Global Change Biology, 16, 3024-3035. https://doi.org/10.1111/j.1365-2486.2009.02147.x, 2010b

Elliott, G. P. (2011). Influences of 20th-century warming at the upper tree line contingent on localscale interactions: evidence from a latitudinal gradient in the Rocky Mountains, USA. Global Ecology and Biogeography, 20, 46-57. https://doi.org/10.1111/j.1466-8238.2010.00588.x

Elliott, G. P. (2012). Extrinsic regime shifts drive abrupt changes in regeneration dynamics at upper treeline in the Rocky Mountains, USA. Ecology, 93, 1614-1625. https://doi.org/10.1890/11-1220.1.

Elliott, G. P., \& Cowell, C. M. (2015). Slope aspect mediates fine-scale tree establishment patterns at upper treeline during wet and dry periods of the 20th century. Arctic, Antarctic, and Alpine Research, 47, 679-690. https://doi.org/10.1657/AAAR0014-025.

Elliott, G. P., \& Petruccelli, C. A. (2018). Tree recruitment at the treeline across the Continental Divide in the Northern Rocky Mountains, USA: the role of spring snow and autumn climate. Plant Ecology \& Diversity. https://doi.org/10.1080/17550874.2018.1487475

Fajardo, A., \& McIntire, E. J. B. (2012). Reversal of multicentury tree growth improvements and loss of synchrony at mountain tree lines point to changes in key drivers. Journal of Ecology, 100, 782-794. https://doi.org/10.1111/j.1365-2745.2012.01955.x.

Gaire, N. P., Koirala, M., Bhuju, D., \& Borgaonkar, H. (2014). Treeline dynamics with climate change at the central Nepal Himalaya. Climate of the Past, 10, 1277-1290. https://doi.org/10.5194/cp-10-1277-2014

Greene, D. F., \& Johnson, E. A. (1995). Long-distance wind dispersal of tree seeds. Canadian 
Journal of Botany, 73, 1036-1045. https://doi.org/10.1139/b95-113

Grömping, U. (2006). Relative importance for linear regression in R: the package relaimpo. Journal of Statistical Software, 17, 1-27. https://doi.org/10.18637/jss.v017.i01

Hagedorn, F., Shiyatov, S. G., Mazepa, V. S., Devi, N. M., Grigor'ev, A. A., Bartysh, A.A., ...Moiseev, P.A. (2014). Treeline advances along the Urals mountain range-driven by improved winter conditions? Global Change Biology, 20, 3530-3543. https://doi.org/10.1111/gcb.12613

Harris, I., Jones, P., Osborn, T., \& Lister, D. (2014). Updated high - resolution grids of monthly climatic observations-the CRU TS3. 10 Dataset. International Journal of Climatology, 34, 623-642. https://doi.org/10.1002/joc.3711

Harsch, M. A., Buxton, R., Duncan, R. P., Hulme, P. E., Wardle, P., \& Wilmshurst, J. (2012). Causes of tree line stability: stem growth, recruitment and mortality rates over 15 years at New Zealand Nothofagus tree lines. Journal of Biogeography, 39, 2061-2071. https://doi.org/10.1111/j.1365-2699.2012.02763.x

Harsch, M. A., Hulme, P. E., Mcglone, M. S., \& Duncan, R. P. (2009). Are treelines advancing? A global meta - analysis of treeline response to climate warming. Ecology letters, 12, 10401049. https://doi.org/10.1111/j.1461-0248.2009.01355.x

Harte, J., \& Shaw, R. (1995). Shifting dominance within a montane vegetation community: results of a climate-warming experiment. Science, $267, \quad 876$. https://doi.org/10.1126/science.267.5199.876

Holtmeier, F., \& Broll, G. (2005). Sensitivity and response of northern hemisphere altitudinal and polar treelines to environmental change at landscape and local scales. Global Ecology and Biogeography, 14, 395-410. https://doi.org/10.1111/j.1466-822X.2005.00168.x 
Huang, M., Piao, S., Janssens, I. A., Zhu, Z., Wang, T., Wu, D., .. Peñuelas J. (2017). Velocity of change in vegetation productivity over northern high latitudes. Nature Ecology \& Evolution, 1, 649-1654. https://doi.org/10.1038/s41559-017-0328-y

IPCC (2014). Climate Change 2014-Impacts, Adaptation and Vulnerability: Regional Aspects, Cambridge University Press.

Kattel, D. B., Yao, T., Yang, K., Tian, L., Yang, G., \& Joswiak, D. (2013). Temperature lapse rate in complex mountain terrain on the southern slope of the central Himalayas. Theoretical and Applied Climatology, 113, 671-682. https://doi.org/10.1007/s00704-012-0816-6

Kharuk, V. I., Ranson, K. J., Im, S. T., \& Vdovin, A. S. (2010). Spatial distribution and temporal dynamics of high-elevation forest stands in southern Siberia. Global Ecology and Biogeography, 19, 822-830. https://doi.org/10.1111/j.1466-8238.2010.00555.x

Kirdyanov, A. V., Hagedorn, F., \& Knorre, A. A., Fedotova, E. V., Vaganov, E. A., Naurzbaev, M. M., ...Rigling, A. (2012). 20th century tree-line advance and vegetation changes along an altitudinal transect in the Putorana Mountains, northern Siberia. Boreas, 41, 56-67. https://doi.org/10.1111/j.1502-3885.2011.00214.x

Körner, C. (2012). Alpine treelines: functional ecology of the global high elevation tree limits, Springer Science \& Business Media. https://doi.org/10.1007/978-3-0348-0396-0

Körner, C., \& Paulsen, J. (2004). A world-wide study of high altitude treeline temperatures. Journal of Biogeography, 31, 713-732. https://doi.org/10.1111/j.1365-2699.2003.01043.x

Kueppers, L. M., Conlisk, E., Castanha, C., Moyes, A. B., Germino, M. J., de Valpine, P., Torn, M. S., \& Mitton, J. B. (2017). Warming and provenance limit tree recruitment across and beyond the elevation range of subalpine forest. Global Change Biology, 23, 2383-2395. https://doi.org/10.1111/gcb.13561. 
Kullman, L., \& Öberg, L. (2009). Post-Little Ice Age tree line rise and climate warming in the Swedish Scandes: a landscape ecological perspective. Journal of Ecology, 97, 415-429. https://doi.org/10.1111/j.1365-2745.2009.01488.x

Lenoir, J., Gégout, J., Marquet, P., De Ruffray, P., \& Brisse, H. (2008). A significant upward shift in plant species optimum elevation during the 20th century. Science, 320, 1768-1771. https://doi.org/10.1126/science.1156831

Li, M. H., \& Yang, J. (2004). Effects of microsite on growth of Pinus cembra in the subalpine zone of the Austrian Alps. Annals of Forest Science, 61, 319-325. https://doi.org/10.1051/forest:2004025

Li, X., Liang, E., Gričar, J., Rossi, S., Čufar, K., \& Ellison, A. M. (2017). Critical minimum temperature limits xylogenesis and maintains treelines on the southeastern Tibetan Plateau. Science Bulletin 62, 804-812. https://doi.org/10.1016/j.scib.2017.04.025

Liang, E., Dawadi, B., Pederson ,N., \& Eckstein, D. (2014). Is the growth of birch at the upper timberline in the Himalayas limited by moisture or by temperature? Ecology, 95, 2453-2465. https://doi.org/10.1890/13-1904.1

Liang, E., Wang, Y., Eckstein, D., \& Luo, T. (2011). Little change in the fir tree-line position on the southeastern Tibetan Plateau after 200 years of warming. New Phytologist, 190, 760-769. https://doi.org/10.1111/j.1469-8137.2010.03623.x

Liang, E., Wang, Y., Piao, S., Lu, X., Camarero, J. J., Zhu, H., ... Peñuelas, J. (2016). Species interactions slow warming-induced upward shifts of treelines on the Tibetan Plateau. Proceedings of the National Academy of Sciences, 113, 4380-4385. https://doi.org/10.1073/pnas.1520582113

Liu. H., \& Yin, Y. (2013). Response of forest distribution to past climate change: An insight into 
future predictions. Chinese Science Bulletin, 58, 4426-4436 https://doi.org/10.1007/s11434013-6032-7.

Lloyd, A. H., \& Graumlich, L. J. (1997). Holocene dynamics of treeline forests in the Sierra Nevada. Ecology, 78, 1199-1210. https://doi.org/10.1890/0012-9658.

Loranger. H., Zotz, G., \& Bader, M. Y. (2017). Competitor or facilitator? The ambiguous role of alpine grassland for the early establishment of tree seedlings at treeline. Oikos, 126, 16251636. https://doi.org/10.1111/oik.04377

Lyu, L., Zhang, Q. B., Deng, X., \& Mäkinen, H. (2016). Fine-scale distribution of treeline trees and the nurse plant facilitation on the eastern Tibetan Plateau. Ecological Indicators, 66, 251258. https://doi.org/10.1016/j.ecolind.2016.01.041

Macias-Fauria, M., \& Johnson, E. A. (2013). Warming-induced upslope advance of subalpine forest is severely limited by geomorphic processes. Proceedings of the National Academy of Sciences, 110, 8117-8122. https://doi.org/10.1073/pnas.1221278110

Miehe, G., Miehe, S., Vogel, J., Co, S., \& La, D. (2007). Highest treeline in the northern hemisphere found in southern Tibet. Mountain Research and Development, 27, 169-173. https://doi.org/10.1659/mrd.0792

Morgan, C., Losey, A., \& Trout, L. (2014). Late-Holocene paleoclimate and treeline fluctuation in Wyoming's Wind River Range, USA. Holocene, 24, 209-219. https://doi.org/10.1177/0959683613516817.

Moyes, A. B., Germino, M. J., \& Kueppers, L. M. (2015). Moisture rivals temperature in limiting photosynthesis by trees establishing beyond their cold-edge range limit under ambient and warmed conditions. New Phytologist, 207, 1005-1014. https://doi.org/10.1111/nph.13422.

Müller, M., Schickhoff, U., Scholten, T., Drollinger, S., Böhner, J., \& Chaudhary, R. P. (2016). 
How do soil properties affect alpine treelines? General principles in a global perspective and novel findings from Rolwaling Himal, Nepal. Progress in Physical Geography, 40, 135-160. https://doi.org/10.1177/0309133315615802

Nathan, R., \& Muller-Landau, H. C. (2000). Spatial patterns of seed dispersal, their determinants and consequences for recruitment. Trends in Ecology \& Evolution, 15, 278-285. https://doi.org/10.1016/S0169-5347(00)01874-7

Peñuelas, J., Ogaya, R., Boada, M., \& Jump, A. S. (2007). Migration, invasion and decline: changes in recruitment and forest structure in a warming-linked shift of European beech forest in Catalonia (NE Spain). Ecography, 30, 829-837. https://doi.org/10.1111/j.2007.09067590.05247.x

Peñuelas, J., Sardans, J., Estiarte, M., Ogaya, R., Carnicer, J., Coll, M., ... Garbulsky, M. (2013). Evidence of current impact of climate change on life: a walk from genes to the biosphere. Global Change Biology, 19, 2303-2338. https://doi.org/10.1111/gcb.12143

Piao, S., Nan, H., Huntingford, C., Ciais, P., Friedlingstein, P., Sitch, S., .. Chen, A. (2014). Evidence for a weakening relationship between interannual temperature variability and northern vegetation activity. Nature Communications, $\quad 5, \quad 5018$. https://doi.org/10.1038/ncomms6018

Piper, F. I., Viñegla, B., Linares, J. C., Camarero, J. J., Cavieres, L. A., \& Fajardo, A. (2016). Mediterranean and temperate treelines are controlled by different environmental drivers. Journal of Ecology, 104, 691-702. https://doi.org/10.1111/1365-2745.12555

R Development Core Team (2017). R: A Language and Environment for statistical Computing (R Foundation for Statistical Computing, Vienna.

Ren, P., Rossi, S., Camarero, J. J., Ellison, A. M., Liang, E., \& Peñuelas J. (2018). Critical 
temperature and precipitation thresholds for the onset of xylogenesis of Juniperus przewalskii in a semi-arid area of the northeastern Tibetan Plateau. Annals of Botany, 121, 617-624. https://doi.org/10.1093/aob/mcx 188

Resler, L. M., Butler, D. R., \& Malanson, G. P. (2005). Topographic shelter and conifer establishment and mortality in an alpine environment, Glacier National Park, Montana. Physical Geography, 26, 112-125. https://doi.org/10.2747/0272-3646.26.2.112

Rossi, S., Anfodillo, T., Cufar, K., Cuny, H. E., Deslauriers, A., Fonti, P., ... Treml, V. (2016). Pattern of xylem phenology in conifers of cold ecosystems at the Northern Hemisphere. Global Change Biology, 22, 3804-3813. https://doi.org/10.1111/gcb.13317

Sano, M., Ramesh, R., Sheshshayee, M., \& Sukumar, R. (2011). Increasing aridity over the past 223 years in the Nepal Himalaya inferred from a tree-ring $\delta^{18} \mathrm{O}$ chronology. The Holocene, 22, 809-817. https://doi.org/10.1177/0959683611430338

Shrestha, B. B., Ghimire, B., Lekhak, H. D., \& Jha, P. K. (2007). Regeneration of treeline birch (Betula utilis D. Don) forest in a trans-Himalayan dry valley in central Nepal. Mountain Research and Development, 27, 259-267. https://doi.org/10.1659/mrdd.0784

Shrestha, D., Singh, P., \& Nakamura, K. (2012). Spatiotemporal variation of rainfall over the central Himalayan region revealed by TRMM Precipitation Radar, Journal of Geophysical Research, 117, D22106. https://doi.org/10.1029/2012JD018140

Shrestha, K. B., Hofgaard, A., \& Vandvik, V. (2014). Recent treeline dynamics are similar between dry and mesic areas of Nepal, central Himalaya. Journal of Plant Ecology, 8, 347358. https://doi.org/10.1093/jpe/rtu035

Thompson, L. G., Mosley-Thompson, E., Brecher, H., Davis, M., León, B., Les, D., ...Mountain, K. (2006). Abrupt tropical climate change: past and present. Proceedings of the National 
Academy of Sciences, 103, 10536-10543. https://doi.org/10.1073/pnas.0603900103

Thompson, L. G., Yao, T., Mosley-Thompson, E., Davis, M., Henderson, K., \& Lin, P. N. (2000). A high-resolution millennial record of the South Asian monsoon from Himalayan ice cores. Science, 289, 1916-1919. https://doi.org/10.1126/science.289.5486.1916

Tiwari, A., Fan, Z. X., Jump, A. S., Li, S. F., \& Zhou, Z. K. (2017). Gradual expansion of moisture sensitive Abies spectabilis forest in the Trans-Himalayan zone of central Nepal associated with climate change. Dendrochronologia, 41, 34-43. https://doi.org/10.1016/j.dendro.2016.01.006

Trujillo, E., Molotch, N. P., Goulden, M. L., Kelly, A. E., \& Bales, R. C. (2012). Elevationdependent influence of snow accumulation on forest greening. Nature Geoscience, 5, 705709. https://doi.org/ 10.1038/ngeo1571

Walther, G. R., Beißner, S., \& Burga, C. A. (2005). Trends in the upward shift of alpine plants. Journal of Vegetation Science, 16, 541-548. https://doi.org/10.1111/j.16541103.2005.tb02394.x

Wang, S. Y., Yoon, J. H., Gillies, R. R., \& Cho, C. (2013). What caused the winter drought in western Nepal during recent years? Journal of climate, 26, 8241-8256. https://doi.org/10.1175/JCLI-D-12-00800.1

Wang, Y., Camarero, J. J., Luo, T., \& Liang, E. (2012). Spatial patterns of Smith fir alpine treelines on the south-eastern Tibetan Platau support that contingent local conditions drive recent treeline patterns. Plant Ecology \& Diversity, 5, 311-321. doi:10.1080/17550874.2012.704647

Wang ,Y., Liang, E., Sigdel, S. R., Liu, B., \& Camarero, J. J. (2017). The couplng of treeline elevaton and temperature is mediated by non-thermal factors on the Tibetan Plateau. Forests, 8, 109. https://doi.org/10.3390/f8040109 
Wang. Y., Pederson, N., Ellison, A. M., Buckley, H. L., Case, B. S., Liang, E., \& Camarero, J. J. (2016). Increased stem density and competition may diminish the positive effects of warming at alpine treeline. Ecology, 97, 1668-1679. https://doi.org/10.1890/15-1264.1

Wang, Y., Zhu, H., Liang, E., \& Camarero, J. J. (2016). Impact of plot shape and size on the evaluation of treeline dynamics in the Tibetan Plateau. Trees-Structure and Function, 30, 1045-1056. https://doi.org/10.1007/s00468-015-1340-y

Wu, H., Guiot, J., Brewer, S., Guo, Z., \& Peng, C. (2007). Dominant factors controlling glacial and interglacial variations in the treeline elevation in tropical Africa. Proceedings of the National Academy of Sciences, 104, 9720-9724. https://doi.org/10.1073/pnas.0610109104

Yao, T., Thompson, L., Yang, W., Yu, W., Gao, Y., Guo, X., ...Joswiak, D. (2012). Different glacier status with atmospheric circulations in Tibetan Plateau and surroundings. Nature Climate Change, 2, 663-667. https://doi.org/10.1038/nclimate1580

Zhu, K., Woodall, C. W., Clark, J. S. (2012). Failure to migrate: lack of tree range expansion in response to climate change. Global Change Biology, 18, 1042-1052. https://doi.org/10.1111/j.1365-2486.2011.02571.x 


\section{Tables}

Table 1. Characteristics of the 20 treeline plots at the six sites in the central Himalayas (site locations are shown in Fig. 1). Treeline features were the main tree species forming the treeline, the type of vegetation above the treeline, the treeline altitude and the vegetation thickness index (TI, plant height $\times$ coverage) for the dominant alpine plant communities situated just above the treeline. Relevant climatic variables were sum of spring precipitation (1998-2015) and mean annual temperature (1970-2014). The last two columns show the annual rate of treeline shift and the altitudinal advance estimated for the last 150 years. The vegetation above the treeline consisted of tall shrubs (TS, 1-2.5 m), short shrubs (SS, 0.5-1 m) and herbs. Plot abbreviations for the six sites: KCA1-3, Kanchenjunga; EV1-3, Everest, LT1-3, Langtang; MN1-3, Manang; J1-3, Jumla and HM1-5, Humla.

\begin{tabular}{|c|c|c|c|c|c|c|c|c|}
\hline Plot & Species & $\begin{array}{c}\text { Vegetation } \\
\text { above the } \\
\text { treeline }\end{array}$ & $\begin{array}{l}\text { Altitude } \\
\text { (m a.s.l) }\end{array}$ & TI & $\begin{array}{c}\text { Spring } \\
\text { precipitation } \\
(\mathrm{mm})\end{array}$ & $\begin{array}{c}\text { Annual } \\
\text { temperature } \\
\left({ }^{\circ} \mathrm{C}\right)\end{array}$ & $\begin{array}{l}\text { Rate of } \\
\text { treeline } \\
\text { advance } \\
\left(\mathrm{m} \mathrm{yr}^{-1}\right)\end{array}$ & $\begin{array}{l}\text { Altitudinal } \\
\text { advance } \\
\text { (m) }\end{array}$ \\
\hline KCA1 & Birch & SS & 4217.2 & 0.52 & 420.6 & 3.68 & 0.20 & 29.5 \\
\hline KCA2 & Birch & $\mathrm{TS}$ & 3809.8 & 0.47 & 420.6 & 5.94 & 0.27 & 40.7 \\
\hline KCA3 & Birch & TS & 3935.4 & 0.25 & 420.6 & 5.29 & 0.37 & 56.1 \\
\hline EV1 & Fir & TS & 4098.5 & 0.43 & 238.3 & 4.14 & 0.10 & 14.6 \\
\hline EV2 & Fir & TS & 4048.9 & 0.42 & 238.3 & 4.40 & 0.34 & 51.7 \\
\hline EV3 & Fir & Herb & 4014.4 & 0.12 & 238.3 & 4.58 & 0.05 & 7.1 \\
\hline LT1 & Birch & SS & 4031.3 & 0.17 & 196.3 & 3.80 & 0.11 & 16.1 \\
\hline LT2 & Birch & SS & 4067.4 & 0.82 & 196.3 & 3.61 & 0.08 & 11.4 \\
\hline LT3 & Birch & SS & 4054.1 & 0.37 & 196.3 & 3.68 & 0.17 & 26.1 \\
\hline MN1 & Fir & SS & 4086.9 & 0.24 & 163.3 & 3.44 & 0.07 & 11.1 \\
\hline
\end{tabular}




\begin{tabular}{ccccccccc} 
MN2 & Birch & SS & 4095.2 & 0.09 & 163.3 & 3.40 & 0.05 & 7.0 \\
MN3 & Birch & SS & 4144.8 & 0.14 & 163.3 & 3.14 & 0.03 & 3.9 \\
J1 & Birch & SS & 3878.1 & 0.58 & 162.4 & 3.67 & 0.04 & 5.5 \\
J2 & Birch & SS & 3834.1 & 0.24 & 162.4 & 3.89 & 0.00 & 0.0 \\
J3 & Birch & SS & 3840.9 & 0.20 & 162.4 & 3.87 & 0.00 & 0.5 \\
HM1 & Birch & SS & 4242.8 & 0.14 & 125.6 & 3.45 & 0.10 & 15.3 \\
HM2 & Birch & SS & 4062.1 & 0.14 & 125.6 & 4.28 & 0.10 & 14.8 \\
HM3 & Birch & SS & 4022.6 & 0.29 & 125.6 & 3.92 & 0.11 & 16.4 \\
HM4 & Fir & SS & 3989.5 & 0.77 & 125.6 & 4.12 & 0.02 & 3.1 \\
HM5 & Fir & SS & 4027.2 & 0.55 & 125.6 & 4.09 & 0.03 & 3.9 \\
\hline
\end{tabular}


Table 2. Percentage of variance $\left(R^{2}\right)$ explained by generalized linear models (GLMs) of the rates of treeline shifts for the 20 plots studied in the central Himalayas. All models included the following variables: altitude, slope, tree species, aspect, distance between the treeline and the species line (SL-TL), plant coverage above the treeline (cover), vegetation thickness index (TI, plant height $\times$ coverage), mean/total annual, spring, summer and winter temperatures (AT, SPT, SUT and WT) and precipitation (AP, SPP, SUP and WP), annual mean maximum (ATmax) and minimum temperature (ATmin), and changes in the mean/total annual, spring, summer and winter temperatures (CAT, CSPT, CSUT and CWT) and precipitation (CAP, CSPP, CSUP and CWP). The relative contributions of the two or three most influential variables are indicated by asterisks (*, ** and $* * *$ indicate $P<0.05, P<0.01$ and $P<0.001$, respectively).

\begin{tabular}{|c|c|c|c|c|c|c|c|c|c|c|}
\hline & & & & Varia & & & & & & $R^{2}(\%)$ \\
\hline Altitude* & Aspect & Slope & Species & $\begin{array}{l}\text { SL- } \\
\text { TL }\end{array}$ & cover & TI & $\mathrm{SPT}^{* * *}$ & SUT $* *$ & WT & 59.9 \\
\hline Altitude & Aspect & Slope & Species & $\begin{array}{l}\text { SL- } \\
\text { TL }\end{array}$ & cover & TI & $\mathrm{SPP} * *$ & SUP** & WP* & 63.8 \\
\hline Altitude & Aspect & Slope & Species & $\begin{array}{l}\text { SL- } \\
\text { TL }\end{array}$ & cover & TI & $\mathrm{CSPT}^{*}$ & $\begin{array}{l}\text { CSUT }^{*} \\
* *\end{array}$ & $\mathrm{CWT}^{* *}$ & 55.4 \\
\hline Altitude & Aspect & Slope & Species & $\begin{array}{l}\text { SL- } \\
\text { TL }\end{array}$ & cover & TI & $\begin{array}{l}\text { CSPP* } \\
*\end{array}$ & CSUP* & $\begin{array}{l}\text { CWP** } \\
*\end{array}$ & 71.2 \\
\hline $\begin{array}{l}\text { Altitude* } \\
*\end{array}$ & Aspect & Slope & Species & $\begin{array}{l}\text { SL- } \\
\text { TL }\end{array}$ & cover & TI & $\mathrm{AT}^{* * *}$ & & & 72.1 \\
\hline Altitude & Aspect & Slope*** & Species & $\begin{array}{l}\text { SL- } \\
\text { TL }\end{array}$ & $\begin{array}{l}\text { cover } \\
* *\end{array}$ & $\mathrm{TI}^{*}$ & ATmin & & & 16.59 \\
\hline $\begin{array}{l}\text { Altitude* } \\
*\end{array}$ & Aspect & Slope* & Species & $\begin{array}{l}\text { SL- } \\
\text { TL }\end{array}$ & $\begin{array}{l}\text { cover } \\
* *\end{array}$ & TI & $\begin{array}{l}\text { ATmax } \\
* * *\end{array}$ & & & 70.92 \\
\hline Altitude & Aspect & Slope & Species & $\begin{array}{l}\text { SL- } \\
\text { TL }\end{array}$ & cover & TI & $\mathrm{AP} * * *$ & & & 51.1 \\
\hline Altitude & Aspect & Slope & Species & $\begin{array}{l}\text { SL- } \\
\text { TL }\end{array}$ & cover & $\mathrm{TI}$ & $\begin{array}{l}\text { CAT** } \\
*\end{array}$ & & & 55.4 \\
\hline Altitude & Aspect & Slope & Species & SL- & cover & TI & CAP** & & & 49.4. \\
\hline
\end{tabular}




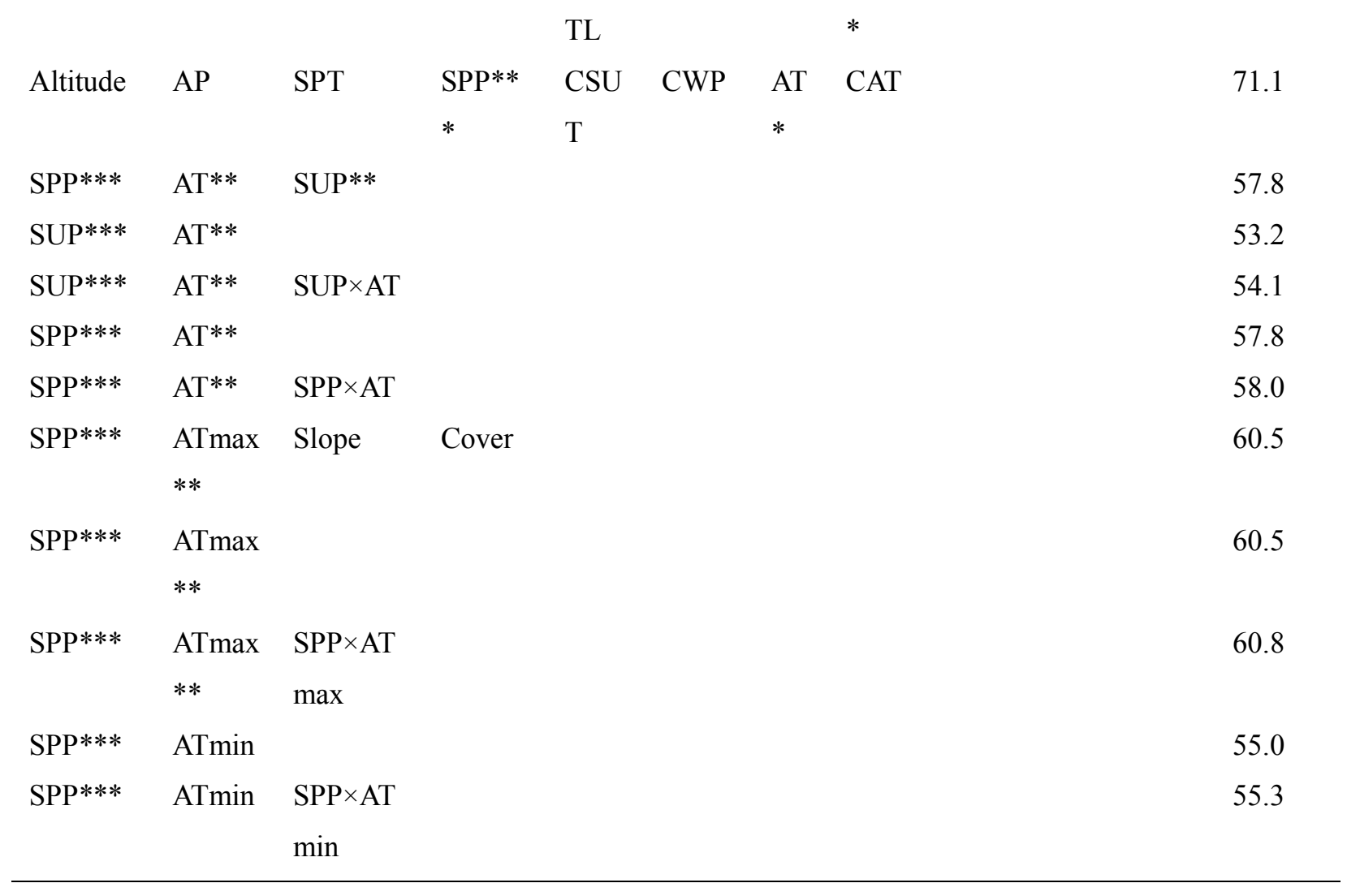




\section{Figure legends}

FIGURE 1 Map showing the locations of the studied treeline plots across the central Himalayas. Triangles represent major mountain peaks near the sites. Blue squares represent plots with Himalaya birch, and yellow squares represent plots with Himalaya fir.

FIGURE 2 Long-term variation of (a) summer temperature reconstructed from climatic proxies $\left({ }^{18} \mathrm{O} /{ }^{16} \mathrm{O}\right.$ ratio in ice cores from various glaciers on the Tibetan Plateau (Thompson et al., 2006), (b) changes in precipitation in the central Himalayas based on tree-ring widths (Liang, Dawadi, Pederson, \& Eckstein, 2014) and (c-h) decadal tree recruitment at the studied Himalayan treelines (six sites, 20 plots; see Figure 1). Decadal recruitment was significantly and positively correlated with mean summer temperature $(r=0.32-0.86)$ reconstructed from the ice cores (see Table S1 in Supporting Information). The red line in ' $b$ ' represents the 10 -year moving average.

FIGURE 3 A three-dimensional diagram depicting the relationships between changes in treeline position during the last 150 years, total spring precipitation and mean annual temperature across the central Himalayas. The surface is based on predictions of fitted generalized linear models (see Table S2 in Supporting Information). Points show actual treeline-shift rate. 


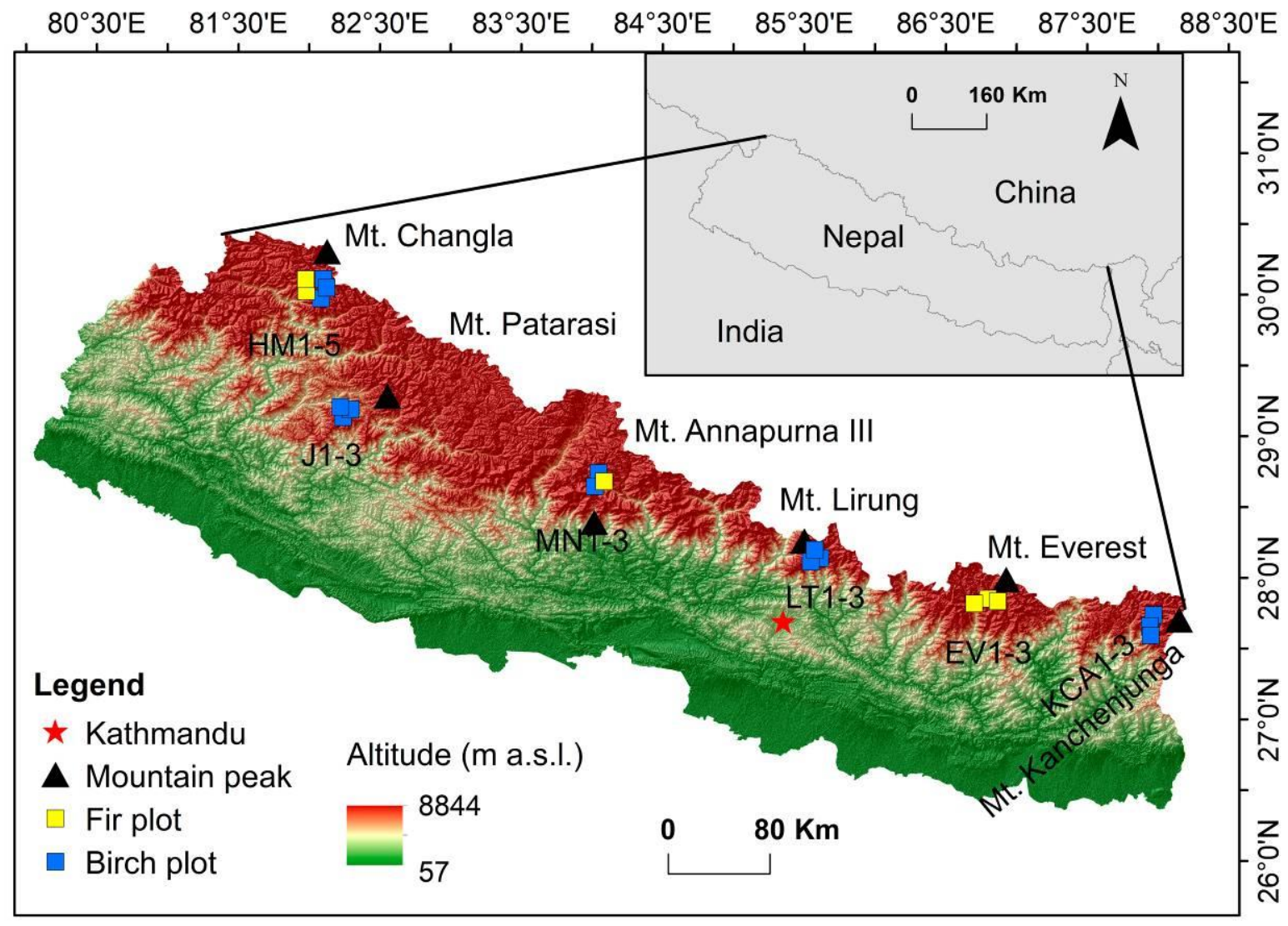

Figure. 1 


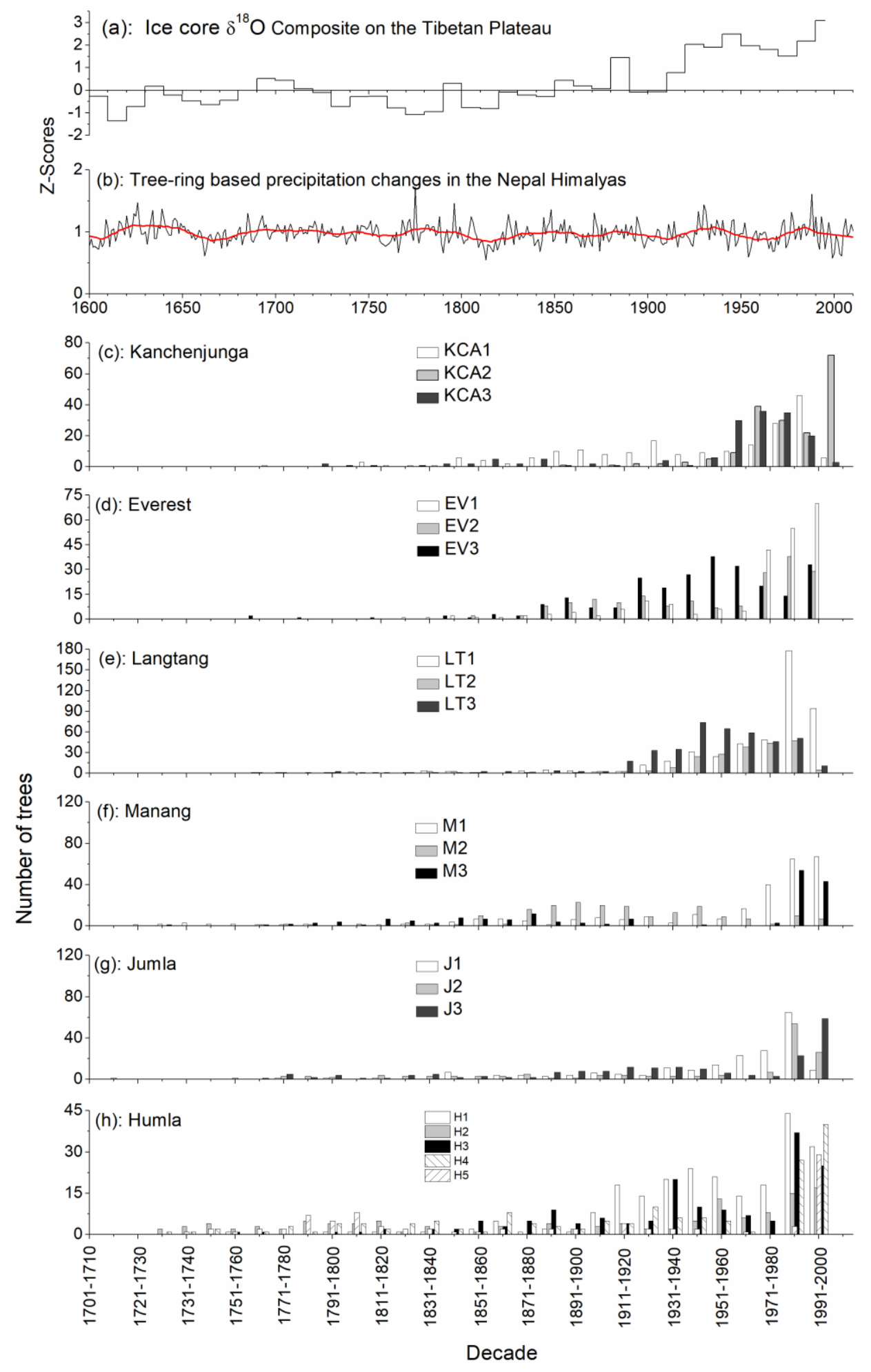

Figure. 2 


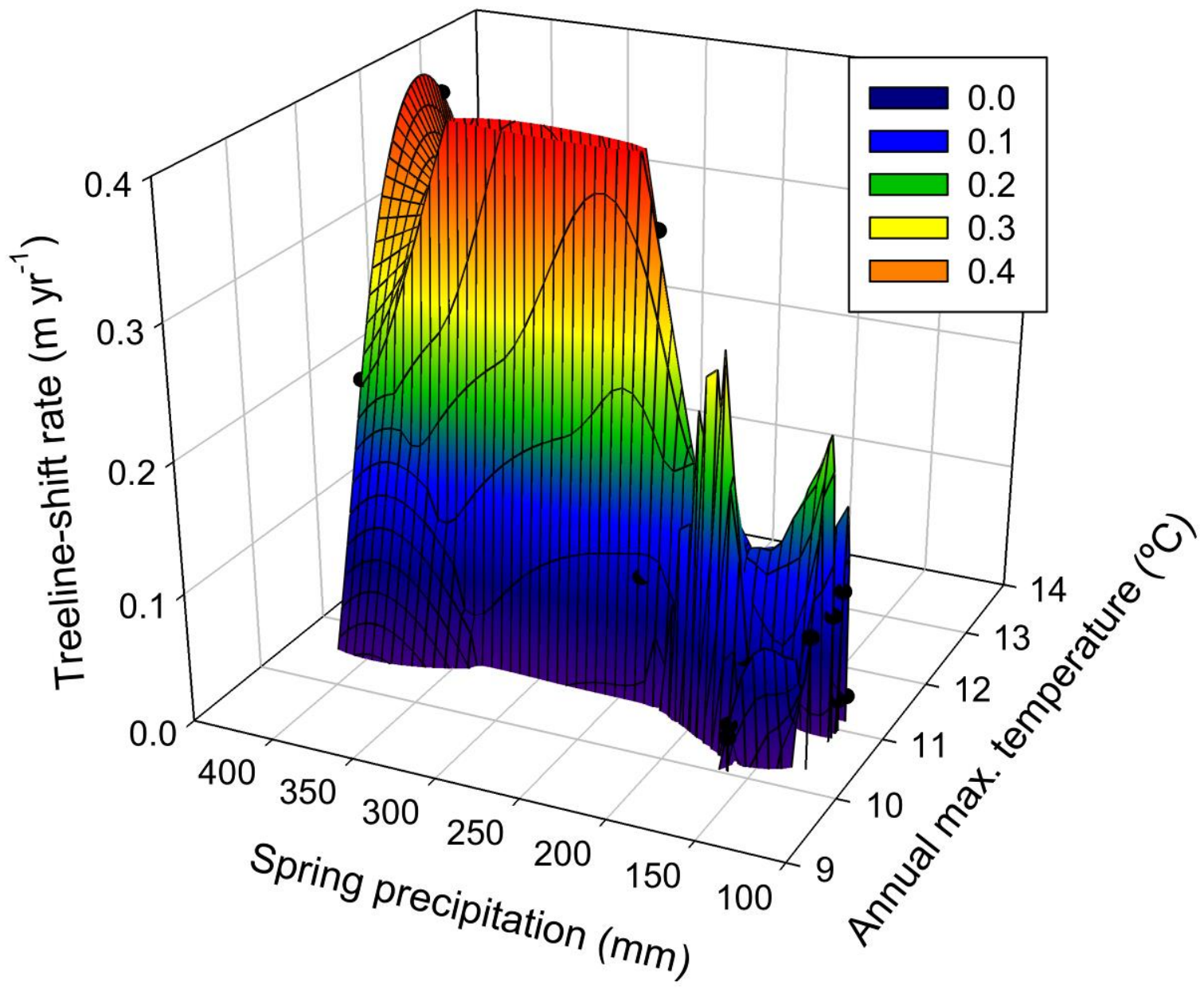

Figure 3. 


\section{Supplementary materials}

Table S1. Corresponding ages (mean $\pm \mathrm{SD}$ ) of treeline trees with a 2 -m height in plots located across the central Himalayas.

\begin{tabular}{llcc}
\hline Tree species & Site & $\begin{array}{c}\text { Tree age at } 2.0 \mathrm{~m} \\
\text { (years) }\end{array}$ & $\begin{array}{c}\text { No. of sampled } \\
\text { trees }\end{array}$ \\
\hline $\begin{array}{llc}\text { Himalayan birch } \\
\text { Betula utilis) }\end{array}$ & Langtang & $20 \pm 6$ & 30 \\
& Everest & $19 \pm 7$ & 20 \\
& Humla & $22 \pm 7$ & 17 \\
& Jumla & $20 \pm 5$ & 21 \\
& Manang & $20 \pm 5$ & 10 \\
& Kanchanjunga & $19 \pm 5$ & 17 \\
Himalayan fir (Abies & Everest & $19 \pm 5$ & 9 \\
spectabilis) & Manang & $22 \pm 5$ & 11 \\
& Humla & $22 \pm 5$ & \\
\hline
\end{tabular}


Table S2. Pearson correlation coefficients $(r)$ and significance levels $(P)$ for the 20 alpine treeline plots between tree recruitment and the mean summer temperature reconstructed from ice cores sampled from various glaciers on the Tibetan Plateau. Correlations were calculated using decadal intervals considering the last 150 years.

\begin{tabular}{lccc}
\hline Plot & Species & $r$ & $P$ \\
\hline KCA1 & Birch & 0.58 & 0.003 \\
KCA2 & Birch & 0.51 & 0.075 \\
KCA3 & Birch & 0.46 & 0.033 \\
EV1 & Fir & 0.62 & 0.006 \\
EV2 & Fir & 0.56 & 0.03 \\
EV3 & Fir & 0.86 & $<0.001$ \\
LT1 & Birch & 0.64 & $<0.001$ \\
LT2 & Birch & 0.62 & $<0.001$ \\
LT3 & Birch & 0.77 & $<0.001$ \\
MN1 & Fir & 0.65 & $<0.001$ \\
MN2 & Birch & 0.38 & 0.065 \\
MN3 & Birch & 0.43 & 0.022 \\
J1 & Birch & 0.52 & 0.011 \\
J2 & Birch & 0.47 & 0.009 \\
J3 & Birch & 0.63 & 0.001 \\
HM1 & Birch & 0.84 & $<0.001$ \\
HM2 & Birch & 0.62 & $<0.001$ \\
HM3 & Birch & 0.73 & $<0.001$ \\
HM4 & Fir & 0.60 & 0.001 \\
HM5 & Fir & 0.32 & 0.08 \\
\hline
\end{tabular}


Table S3. Partial correlation coefficients between treeline shifts and climatic variables through controlling other factors $(\mathrm{n}=20)$. Correlations with one asterisk indicate $P<0.05$. Variables' abbreviations: AT, annual mean temperature; SPP; spring precipitation; SUP, summer precipitation.

\begin{tabular}{lcc}
\hline Variable & Partial correlation coefficients with treeline shifts & Controlled factors \\
\hline AT & $0.234(\mathrm{P}=0.348)$ & SPP, SUP \\
SPP & $0.314(\mathrm{P}=0.202)$ & AT, SUP \\
SUP & $-0.011(\mathrm{P}=0.962)$ & AT, SPP \\
AT & $0.478^{*}(\mathrm{P}=0.038)$ & SUP \\
SPP & $0.514^{*}(\mathrm{P}=0.024)$ & SUP \\
SUP & $-0.115(\mathrm{P}=0.639)$ & SPP \\
\hline
\end{tabular}



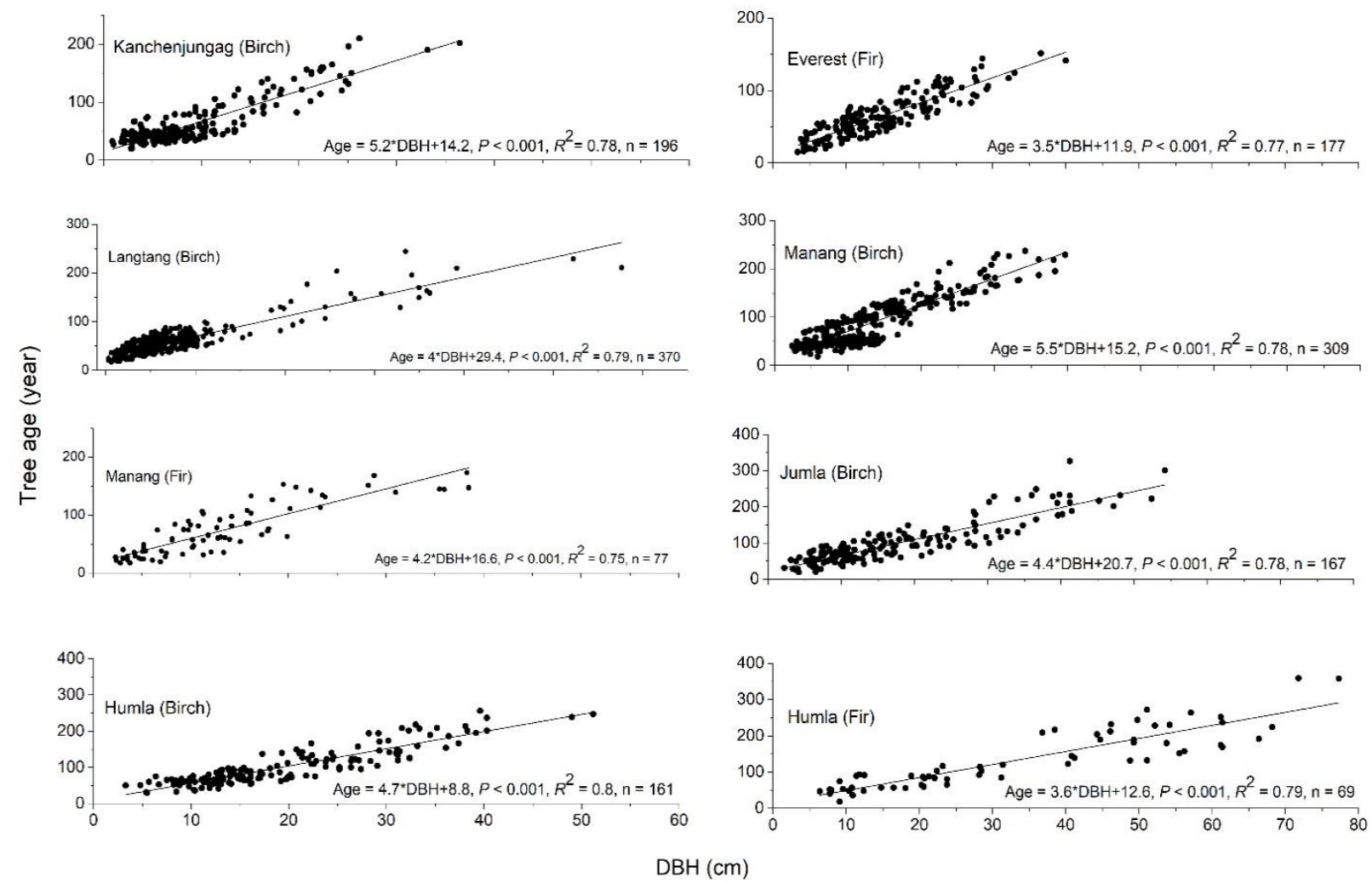

Figure S1. Relationships between tree age and diameter at breast height (DBH) in the treeline plots sampled in the central Himalayas. Tree species (birch, fir), site and regression equations are presented in each plot. The equations were used to calculate the age of trees with a rotten center or missing pith. 
Kanchanjunga 1

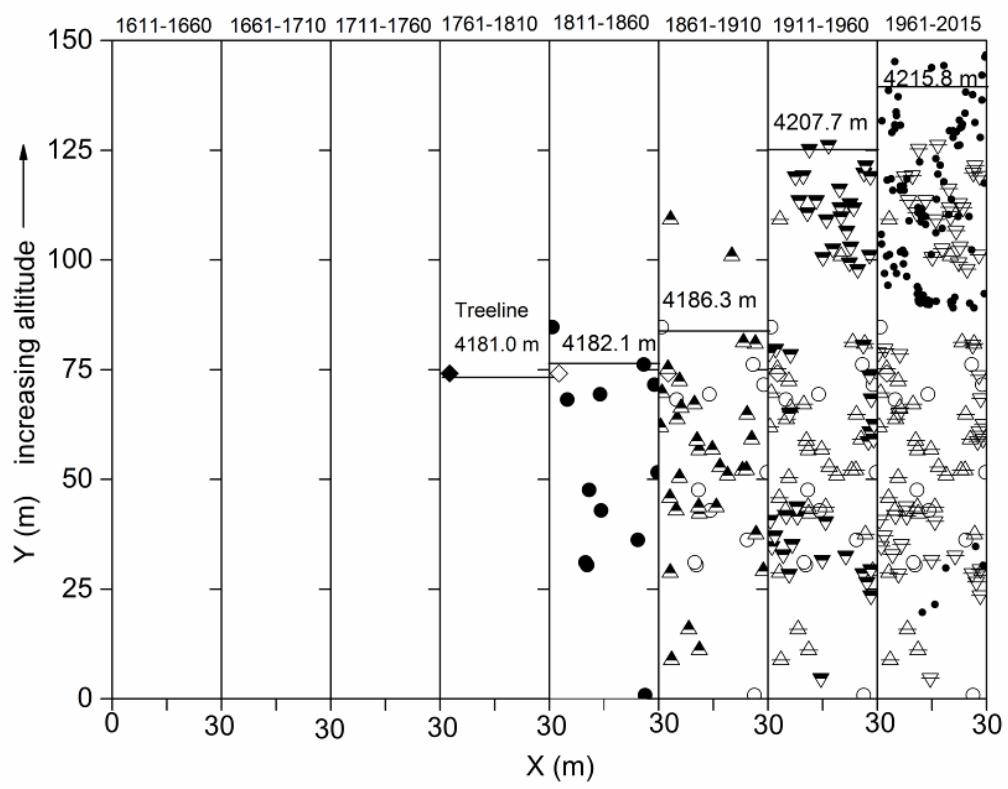

Kanchanjunga 2

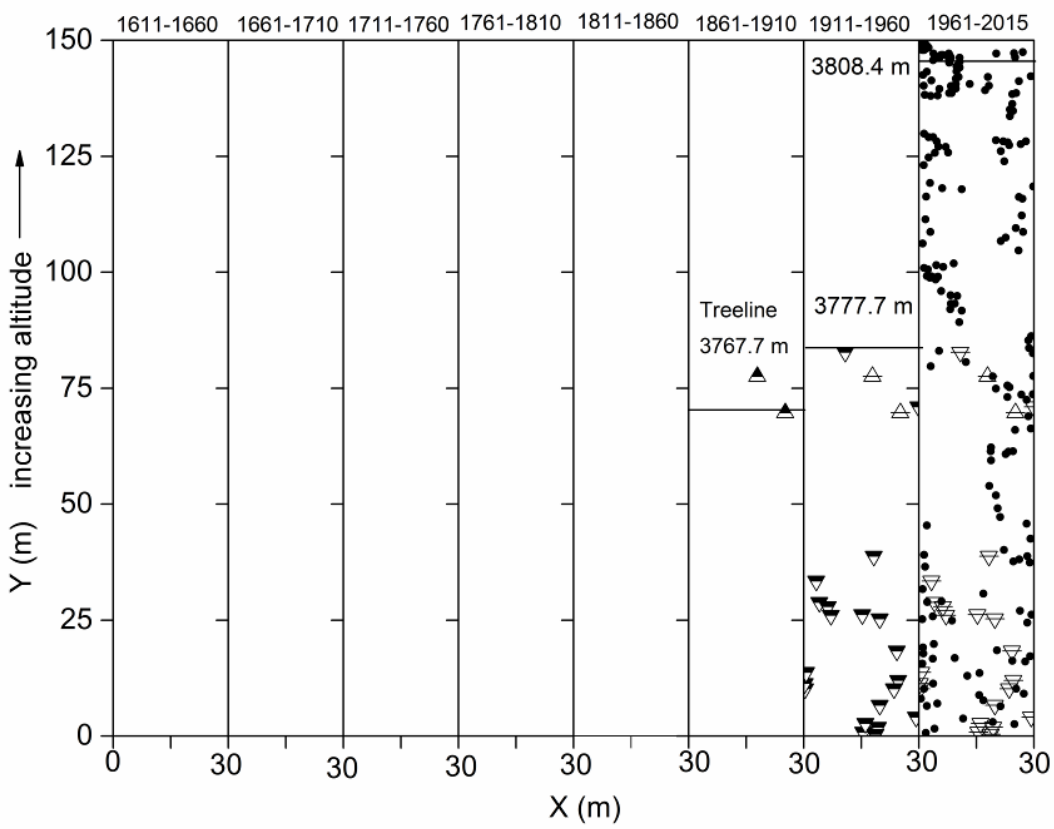


Kanchanjunga 3

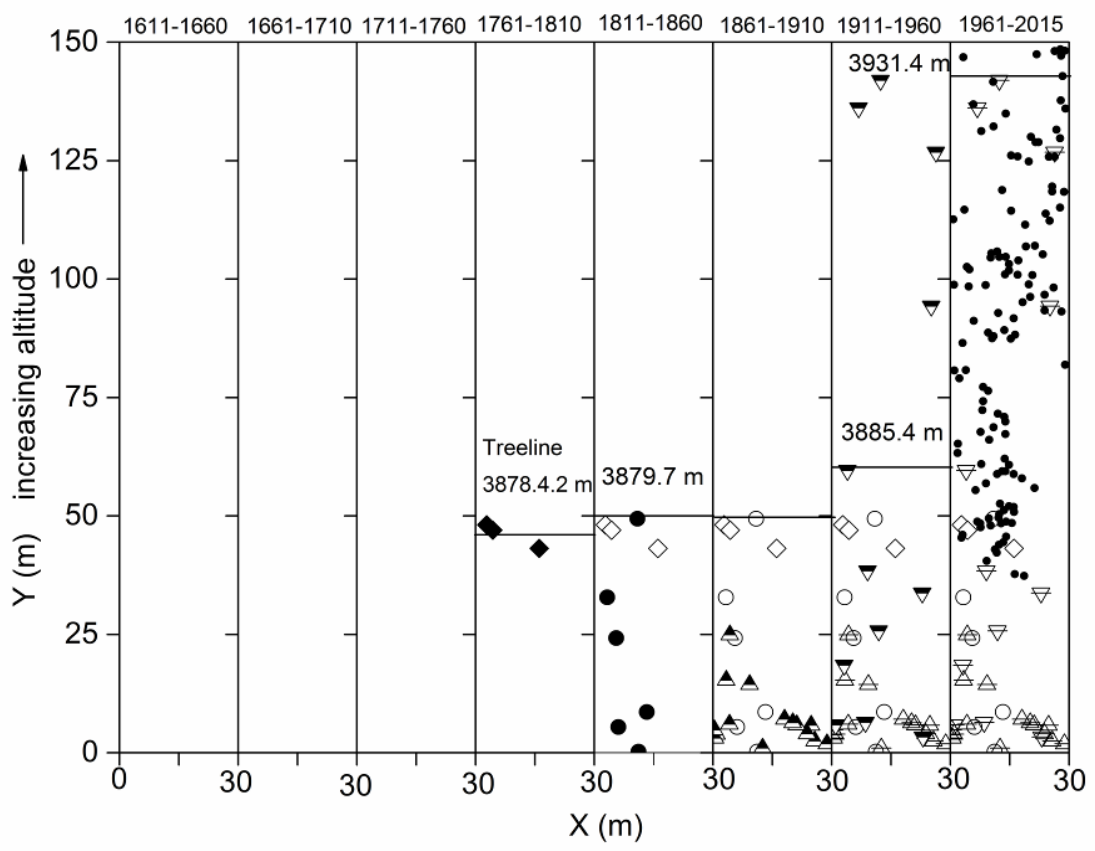

Everest 1

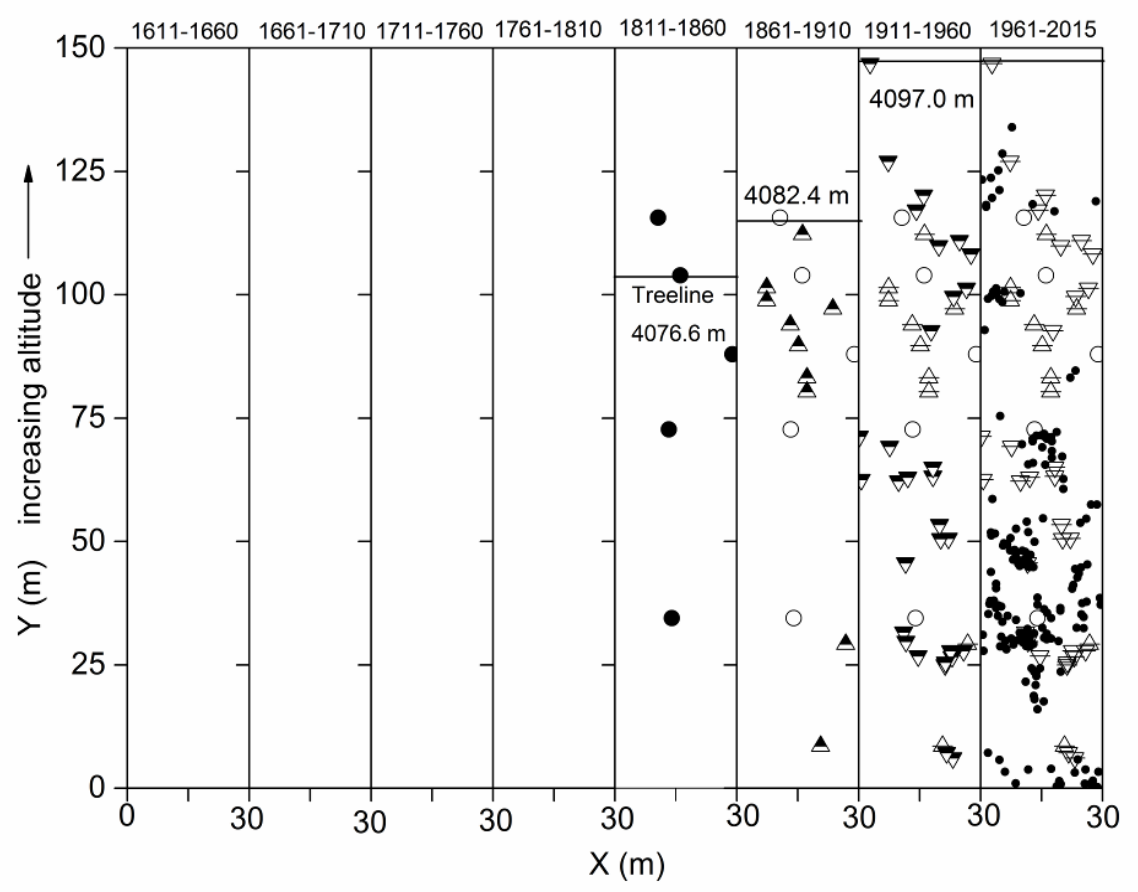


Everest 2

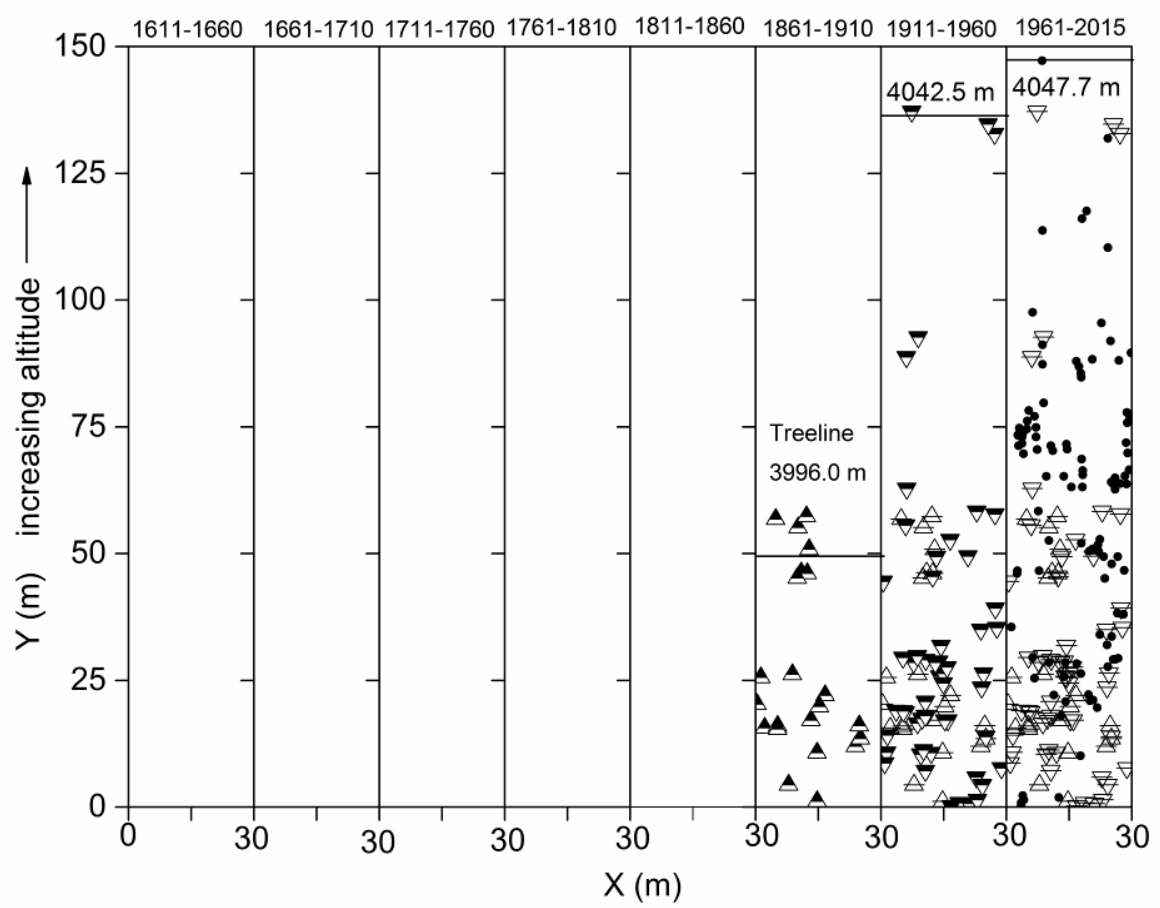

Everest 3

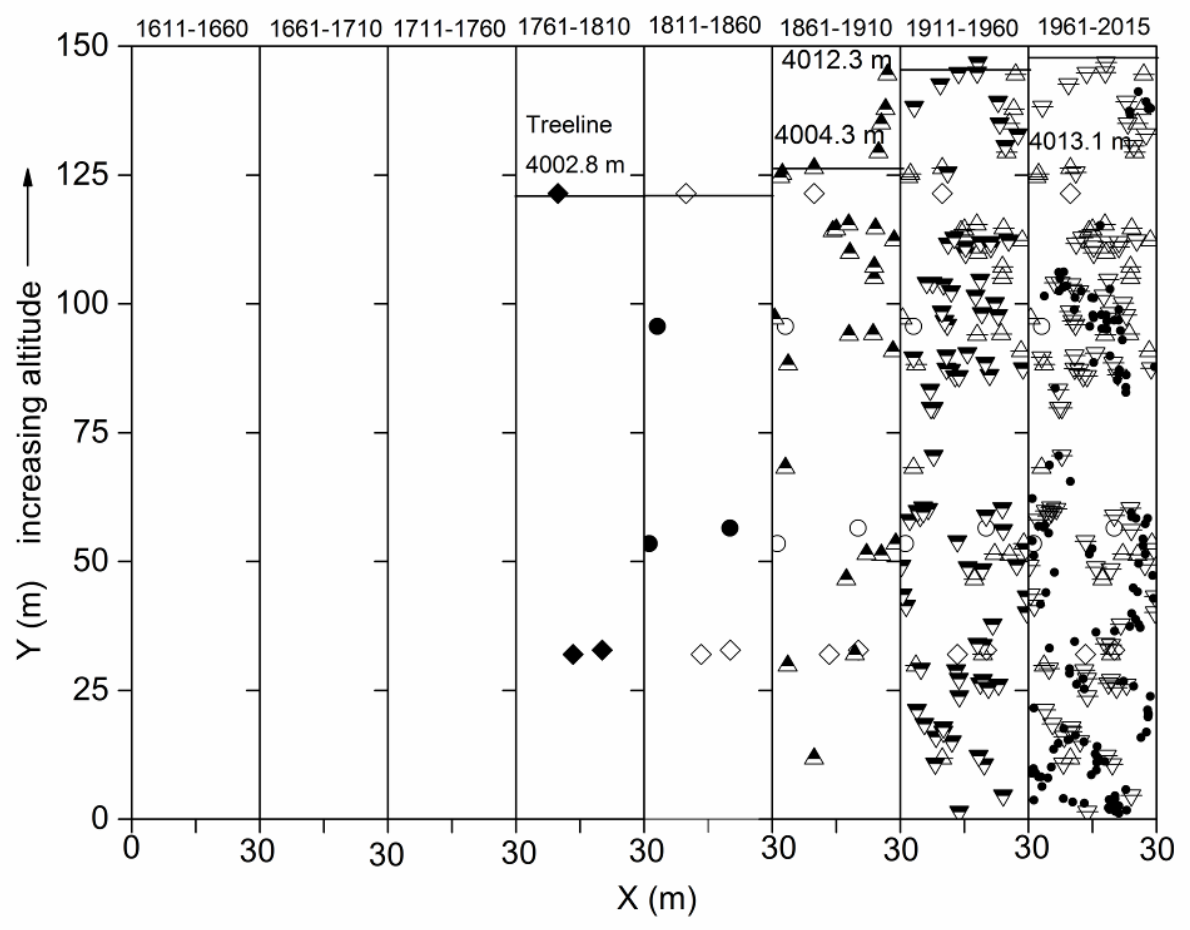


Langtang1

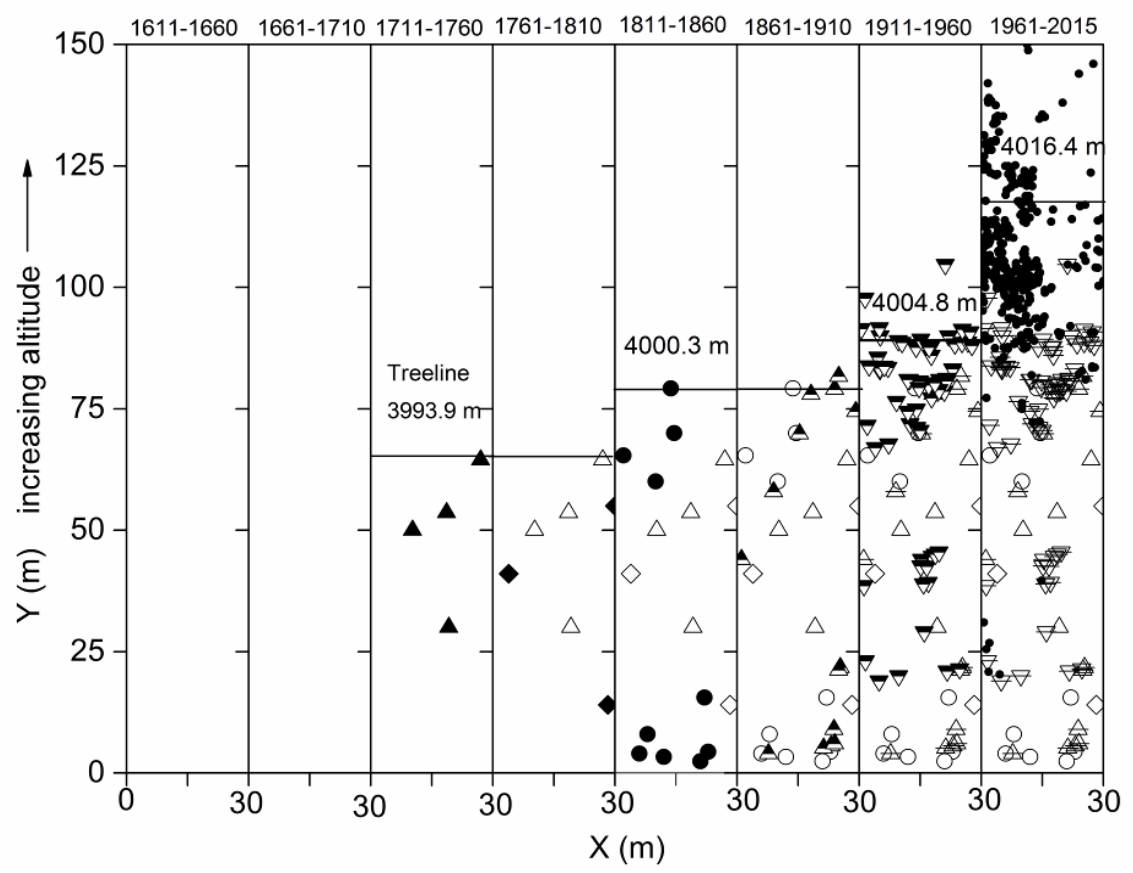

Langtang 2

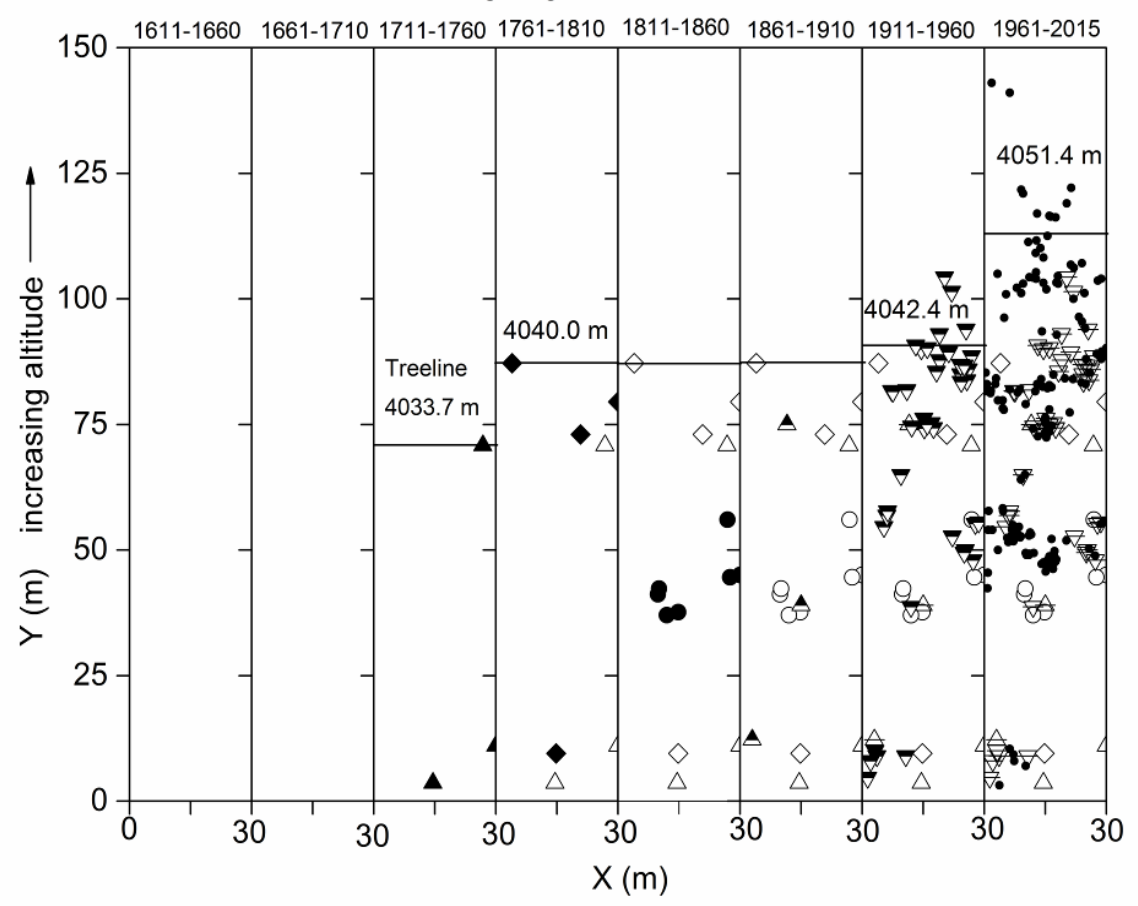


Langtang 3

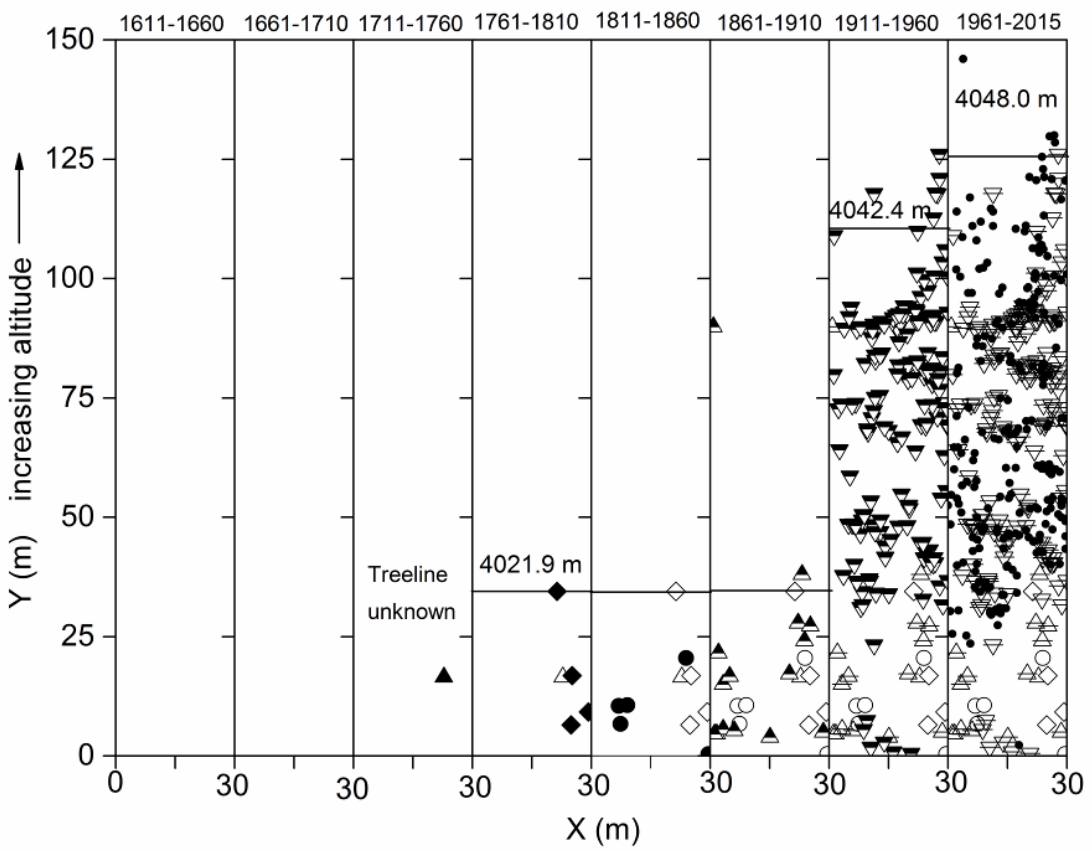

Manang 1

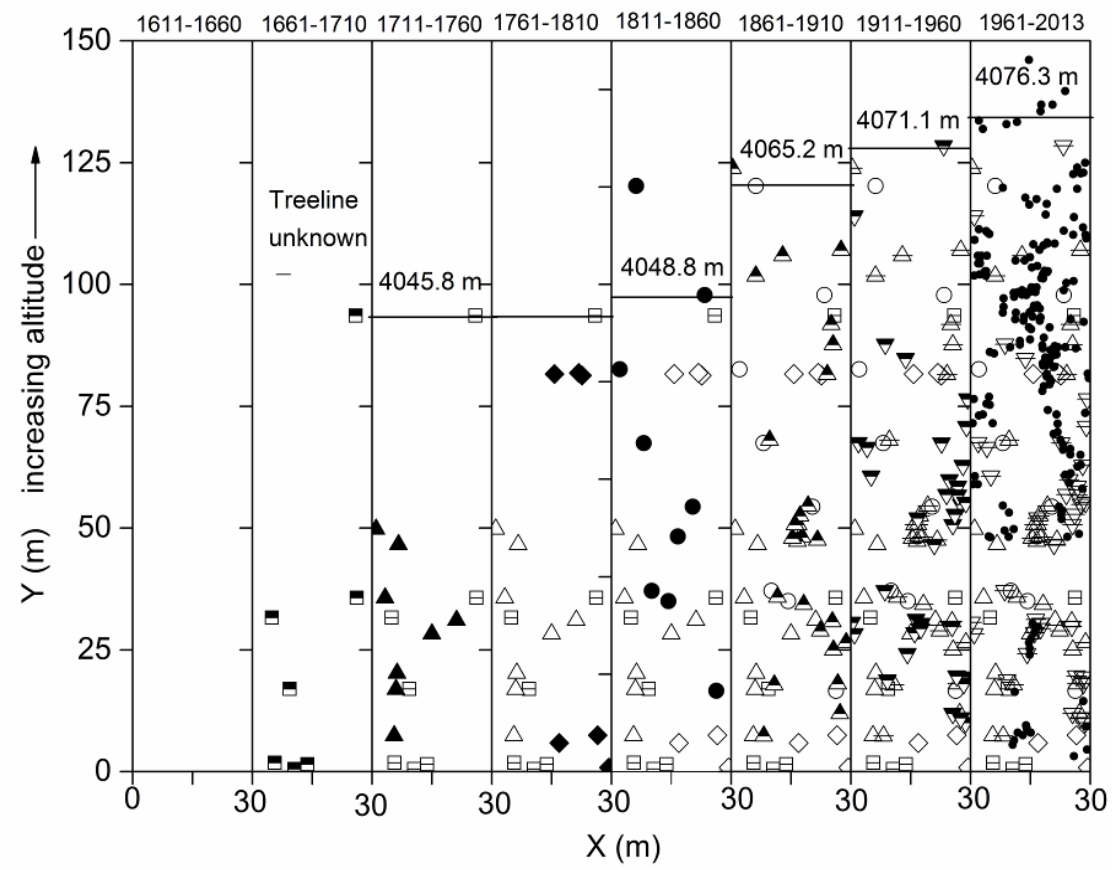


Manang 2

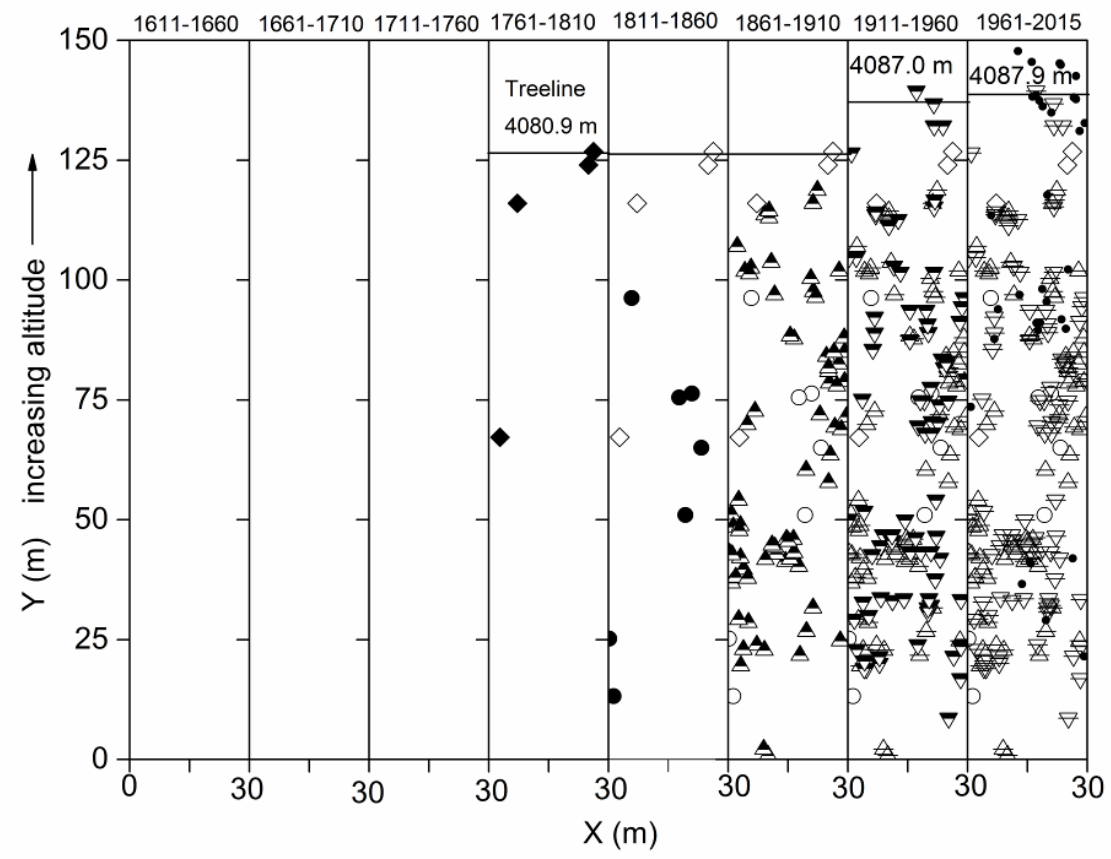

Manang 3

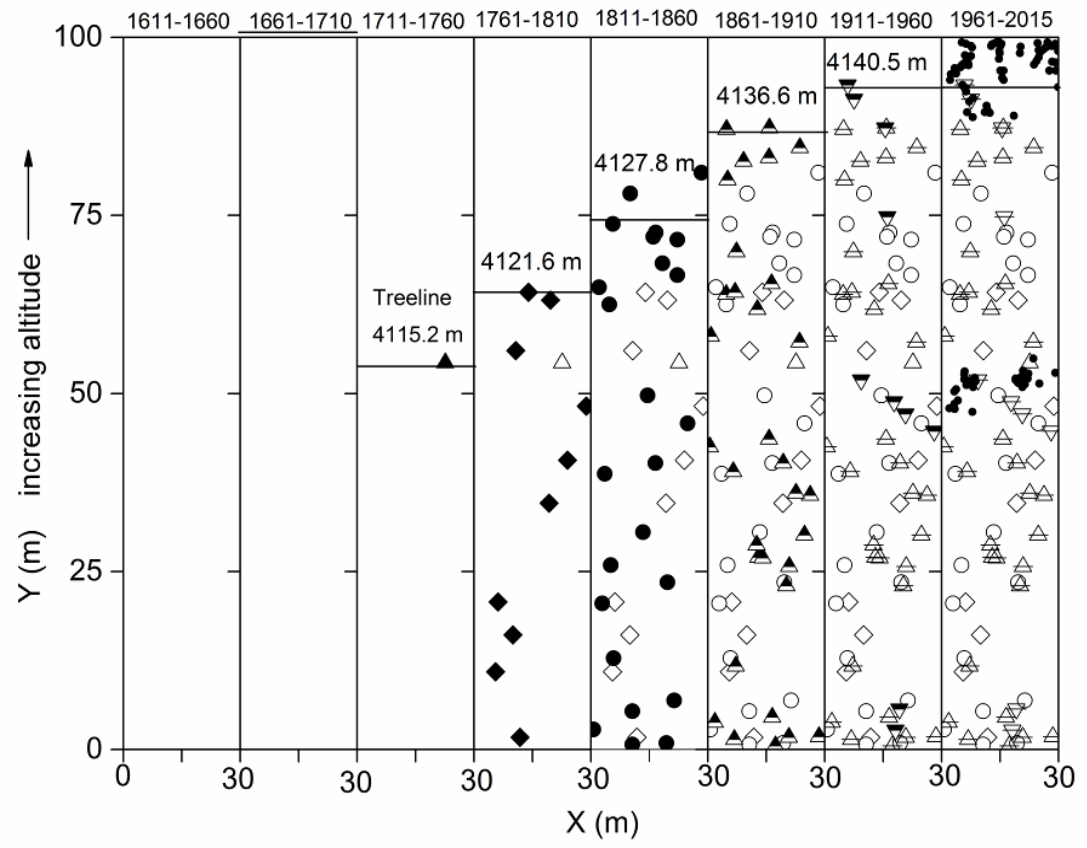


Jumla 1

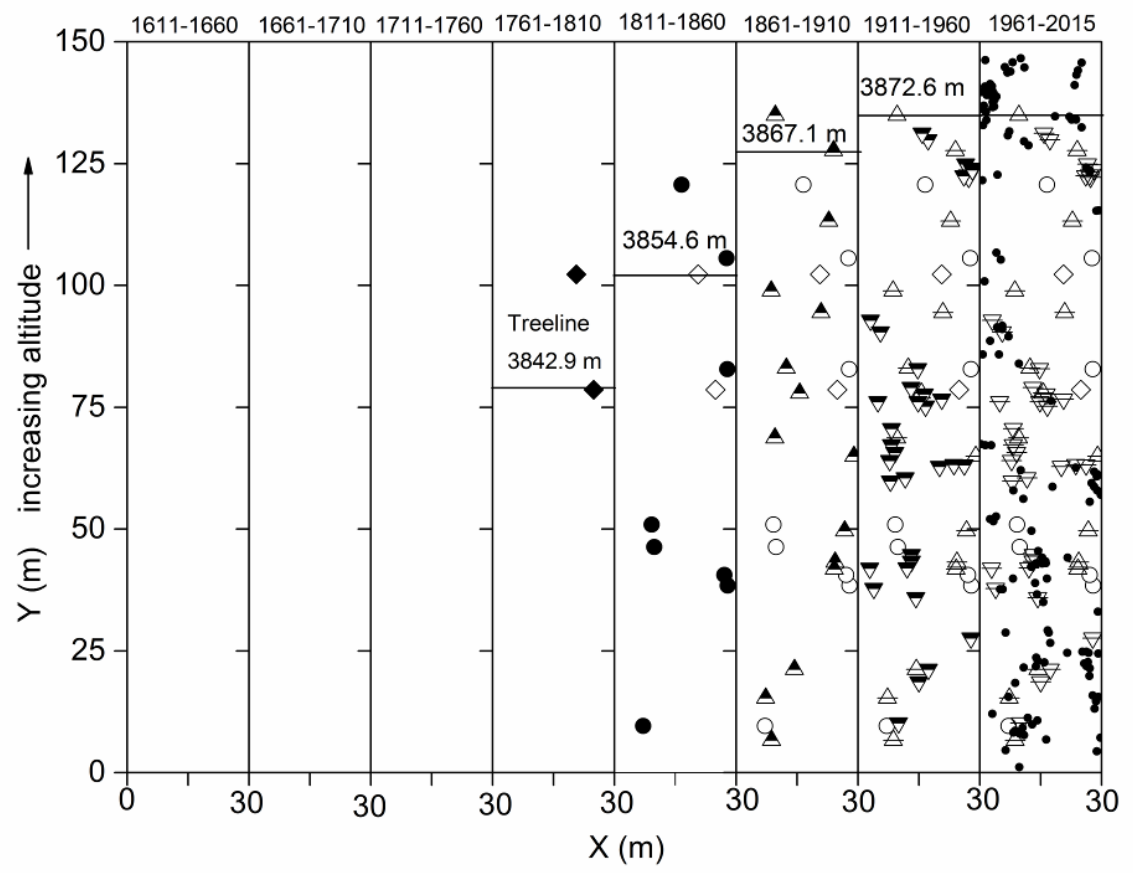

Jumla 2

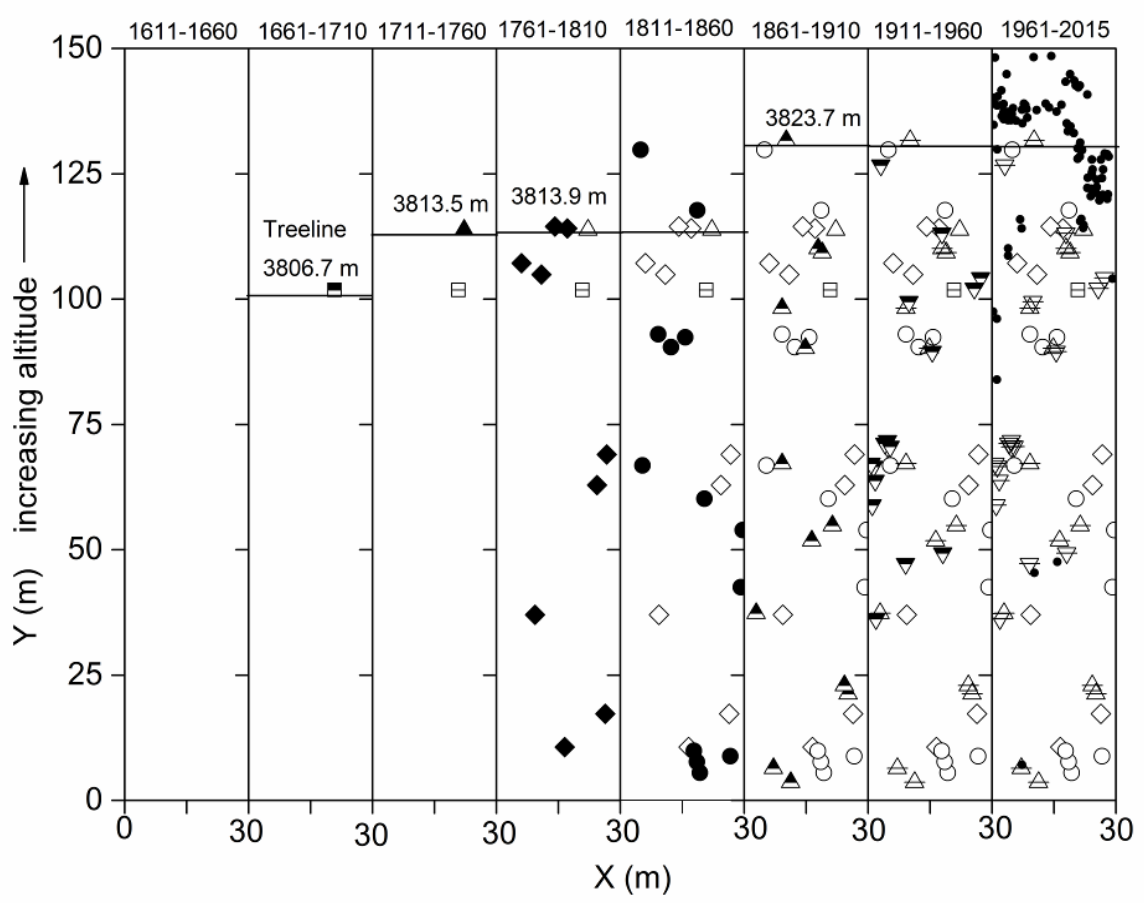


Jumla 3

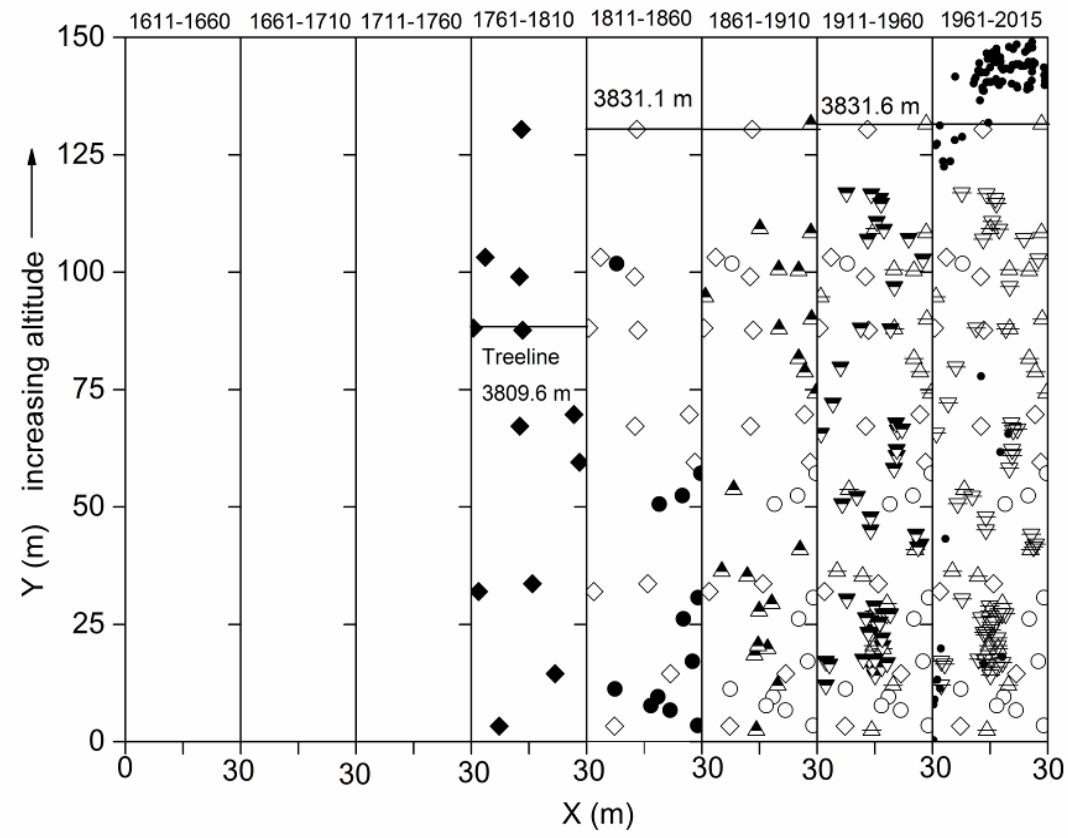

Humla 1

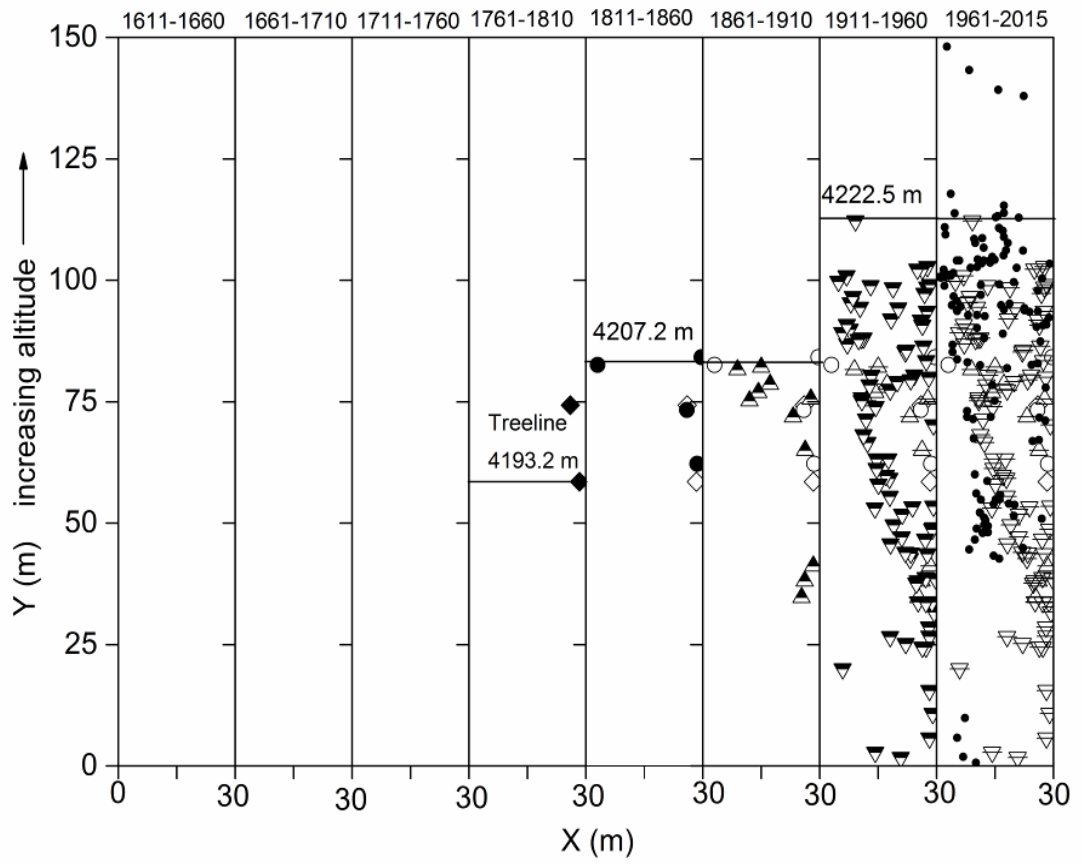


Humla 2

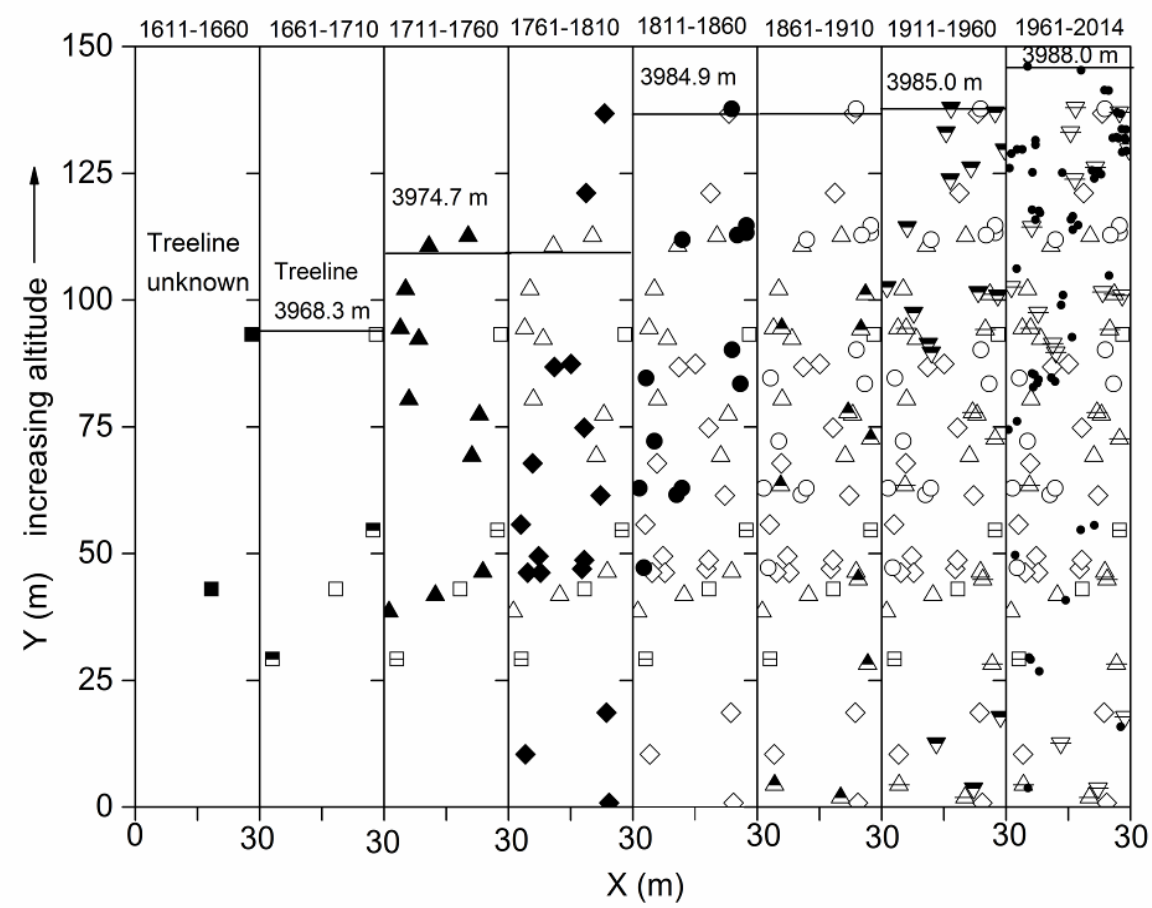

Humla 3

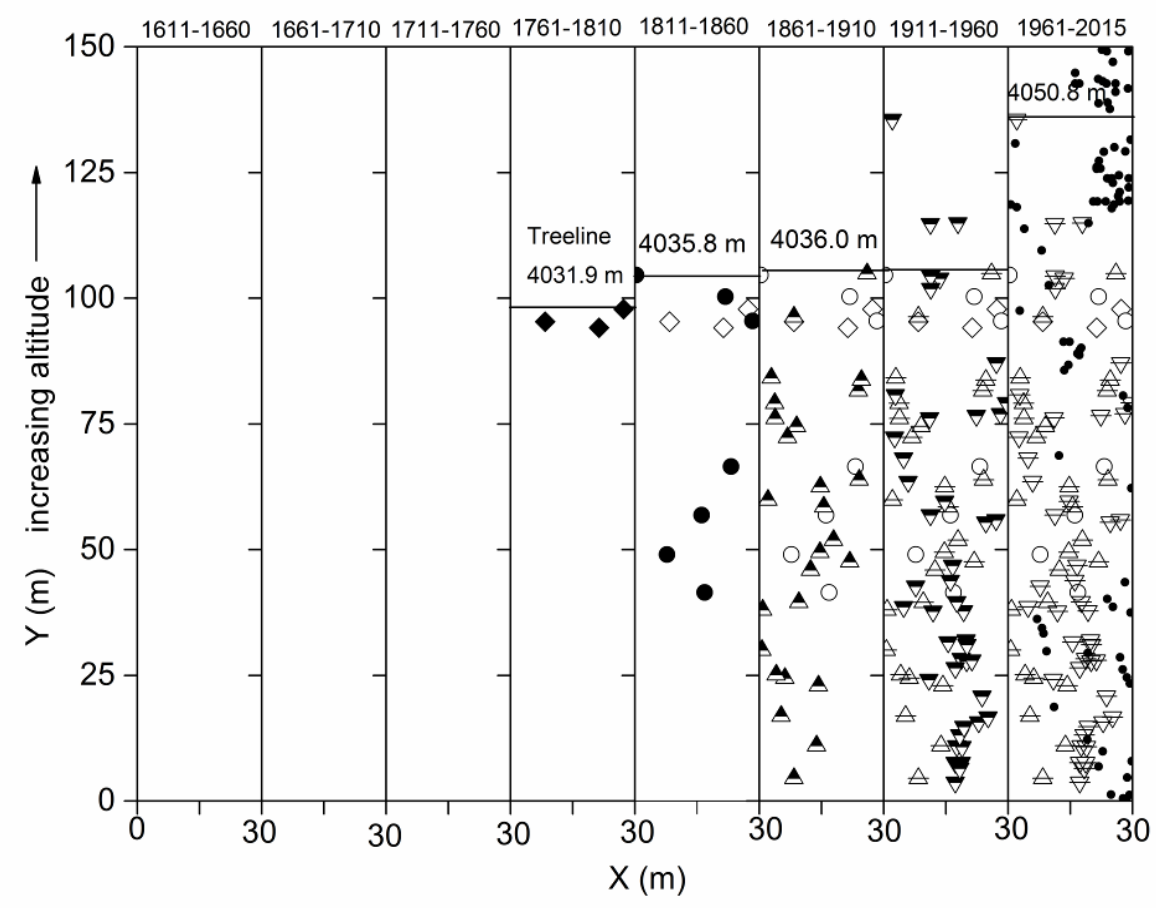


Humla 4

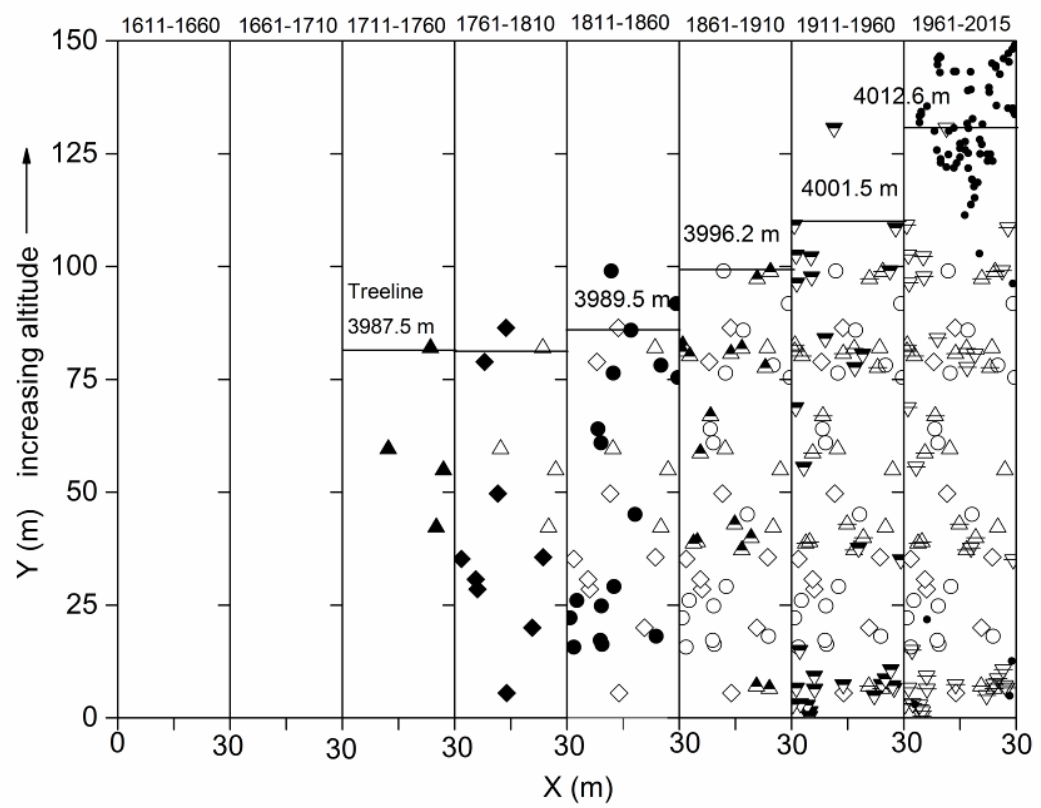

Humla 5

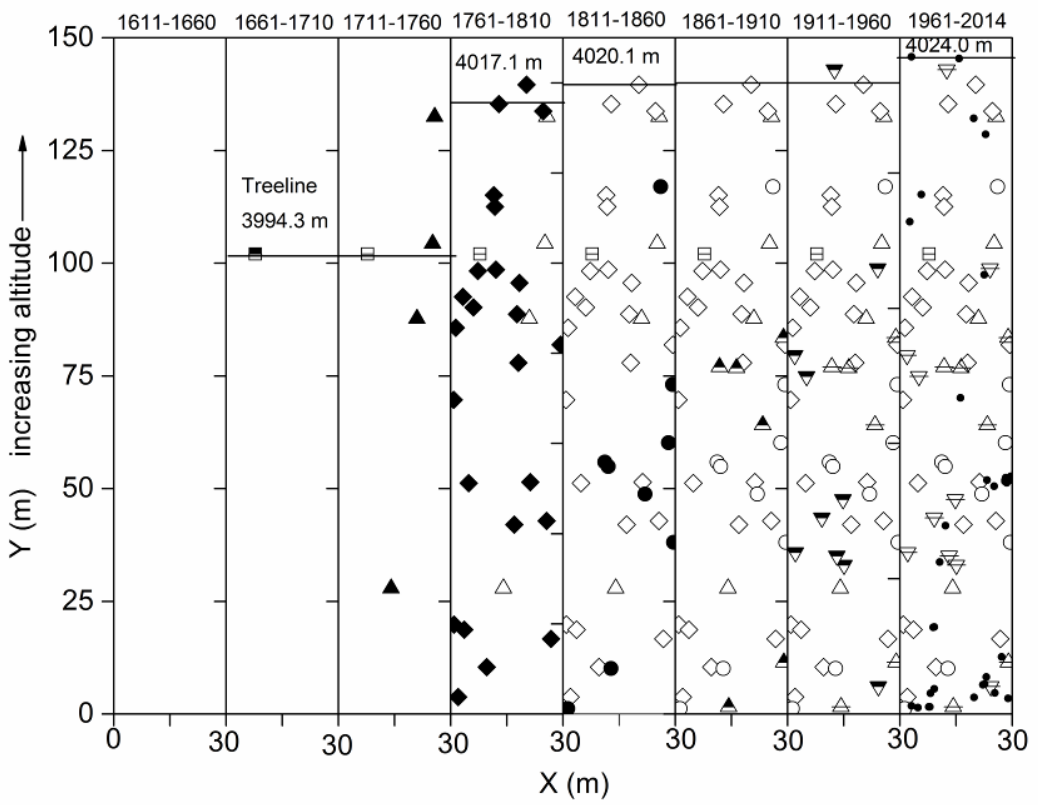

Figure S2. Spatiotemporal variability in tree recruitment and treeline position (upper limit of living trees at least $2 \mathrm{~m}$ tall; this altitude is represented by horizontal lines) reconstructed for Himalayan alpine treeline ecotones from the $17^{\text {th }}$ to the $21^{\text {st }}$ centuries (site and plot numbers are presented at the tops of each panel; see also Table 1 and Fig. 1). Closed symbols in the respective 50-year intervals represent trees that established during that period (indicated at the top of each window). Open symbols represent trees that established in previous 50-year periods. The shapes of the symbols represent the establishment periods (e.g. upward triangles represent trees established during 1711-1760). 

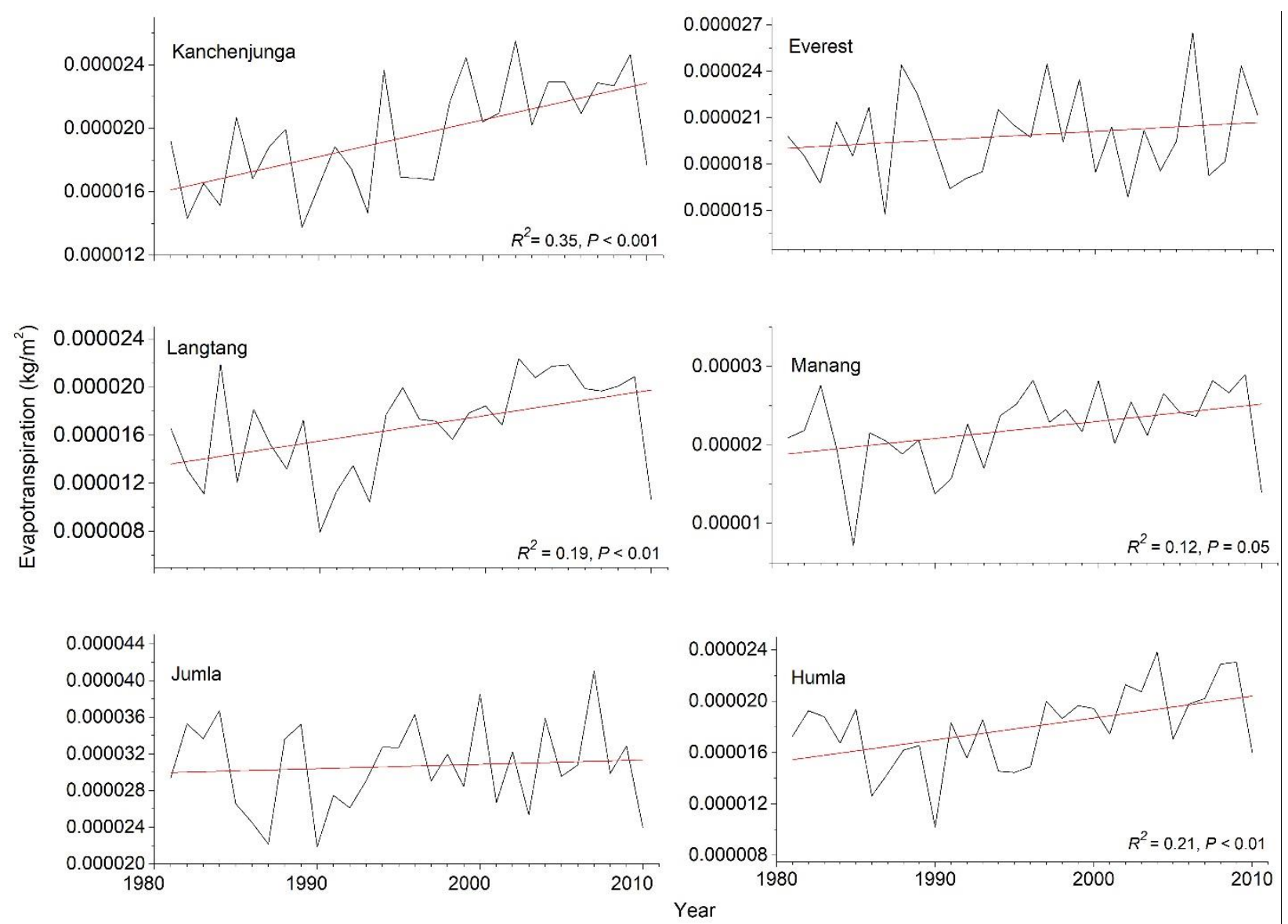

Figure S3. Variations in total monthly evapotranspiration in sites arranged across an east to west gradient in the central Himalayas. Data were retrieved from the satellite-based Global Land Data Assimilation System (GLDAS) model $\left(0.25^{\circ}\right.$ spatial resolution). Evapotranspiration increased significantly in four out of the six sites (statistics are presented). 

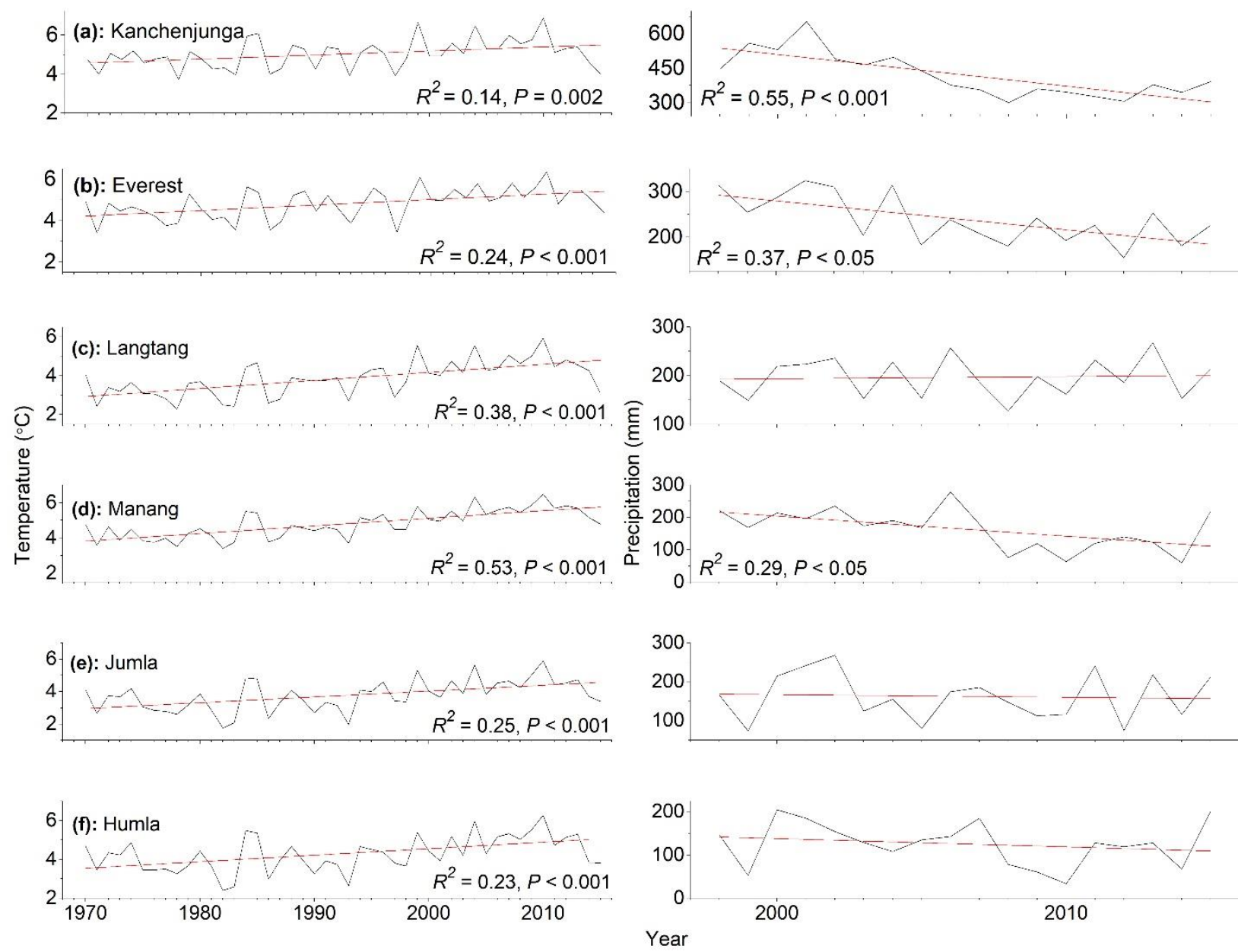

Figure S4. Variations in spring (March-May) temperature (1970-2014) and precipitation (19982015) from east to west in the central Himalayas. Temperature data were retrieved from nearby $0.5^{\circ}$ grids of the Climate Research Unit database, whereas precipitation data were retrieved from the Tropical Rainfall Measuring Mission database at a spatial resolution of $0.25^{\circ}$. Study sites are: (a) Kanchenjunga in eastern Nepal, (b) Khumbu valley near Mt. Everest, (c) Langtang valley, (d) Manang valley, (e) Jumla region and (f) Humla in western Nepal. Spring temperature across all sites increased significantly (statistics are presented), but spring precipitation either decreased or did not change significantly at some sites. 


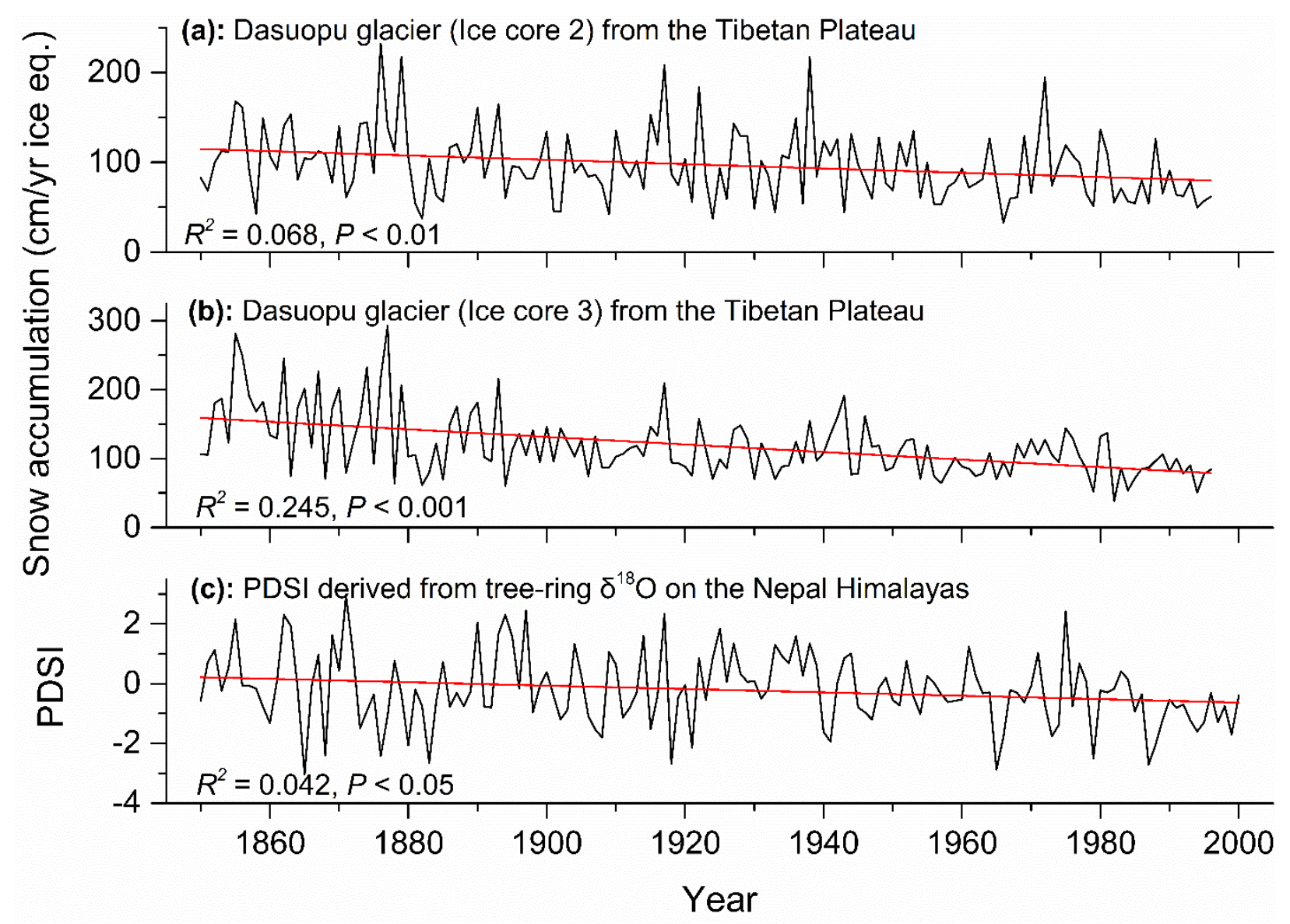

Figure S5. Long-term variation trends in: $(a-b)$ annual snow accumulation rate reconstructed from the $\delta^{18} \mathrm{O}$ in ice cores of the Dasuopu glacier on the Tibetan Plateau (Thompson et al., 2000); (c) the reconstructed July-September Palmer Drought Severity Index (PDSI) based on ring-width variability in trees from north-western Nepal Himalayas forests (Sano, Ramesh, Sheshshayee, \& Sukumar, 2011). 